\title{
Human brown adipose tissue and metabolic health: Potential for therapeutic avenues
}

Rajan Singh ${ }^{1,2,3}$, Albert Barrios ${ }^{2,4}$, Golnaz Dirakvand ${ }^{4}$, Shehla Pervin ${ }^{1,2,4}$

${ }^{1}$ Department of Obstetrics and Gynecology, David Geffen School of Medicine at University of

California Los Angeles (UCLA), Los Angeles, CA, United States.

${ }^{2}$ Division of Endocrinology and Metabolism, Charles R Drew University of Medicine and Science, Los

Angeles, CA, United States.

${ }^{3}$ Department of Endocrinology, Men's Health: Aging and Metabolism, Brigham and Women's Hospital, Boston, MA, United States.

${ }^{4}$ Department of Biology, California State University, Dominguez Hills, Los Angeles, CA, United States.

\section{Correspondence to:}

Rajan Singh, PhD.

E-mail: rajansingh@mednet.ucla.edu

Keywords: Brown adipose tissue; beige adipose tissue; obesity; cold exposure; uncoupling protein-1, beta-adrenergic receptor; energy expenditure; adipose browning; micro-RNA 


\section{Abstract}

Obesity-associated metabolic abnormalities comprise of a cluster of conditions including dyslipidemia, insulin resistance, diabetes, and cardiovascular diseases that has affected more than 650 million people all over the globe. Obesity results from accumulation of white adipose tissues mainly due to the chronic imbalance of energy intake and energy expenditure. Variety of approaches to treat or prevent obesity, including lifestyle interventions, surgical weight loss procedures and pharmacological approaches to reduce energy intake and increase energy expenditure have failed to substantially decrease the prevalence of obesity. Brown adipose tissue (BAT), the primary source of thermogenesis in infants and small mammals may represent a promising therapeutic target to treat obesity by promoting energy expenditure through non-shivering thermogenesis mediated by mitochondrial uncoupling protein 1 (UCP1). Since the confirmation of functional BAT in adult humans by several groups, approximately a decade ago and its association with a favorable metabolic phenotype, intense interest on the significance of BAT in adult human physiology and metabolic health has emerged within the scientific community to explore its therapeutic potential for the treatment of obesity and metabolic diseases. Substantially decreased BAT activity in individuals with obesity indicates a role for BAT in setting of human obesity. On the other hand, BAT mass and its prevalence has been reported to correlate with lower body mass index (BMI), decreased age and glucose levels, leading to lower incidence of cardio metabolic diseases. Increased cold exposure in adult humans with undetectable BAT was associated with decreased body fat mass and increased insulin sensitivity. Deeper understanding of the role of BAT in human metabolic health and its inter-relationship with body fat distribution and deciphering proper strategies to increase energy expenditure by either increasing functional BAT mass, or inducing white adipose browning holds the promise for possible therapeutic avenues for the treatment of obesity and associated metabolic disorders. 


\section{Introduction}

The prevalence of obesity and related metabolic complications have significantly increased worldwide. Obesity represents a major global challenge that increases the risk for several chronic diseases including hypertension, fatty liver disease, diabetes, insulin resistance, dementia, osteoarthritis, sleep apnea and some types of cancer. Thus, obesity presents a substantial burden, both at the individual and population levels, by significantly affecting quality of life as well as socio-economic productivity. Typical therapeutic approaches targeting dietary intake and physical exercise aimed at reducing obesity and related metabolic complications has not provided long-term health benefits, suggesting that there remains an unmet need for development of novel strategies for the treatment and prevention of obesity and associated metabolic complications. Since obesity mainly develops from surplus energy stored in the adipose tissues, therapeutic strategies directed against increasing the energy expenditure and reducing the energy intake, or both provide attractive avenues to combat obesity-associated metabolic complications. BAT, by virtue of its ability to modulate organism's global energy expenditure in the form of heat, has been a subject of tremendous interest to counteract obesity related diseases. This remarkable capacity of BAT to dissipate energy is mediated via upregulation of brown-fat specific mitochondrial uncoupling protein 1 (UCP1) expression. In addition to its primary role in regulating thermogenesis, BAT is also involved in cross talk with several peripheral tissues including liver, skeletal muscle, gut, central nervous system and immune cells to control systemic energy balance and glucose homeostasis. It was widely believed that BAT is present in significant amounts only in newborns, infants and patients with pheochromocytoma and it declines with age in adults. However, over the past few years, major technological advancements in clinical studies using ${ }^{18 f l u o r o-2-d e o x y g l u c o s e ~ p o s i t r o n ~}$ emission tomography $\left({ }^{18} \mathrm{FDG}-\mathrm{PET}\right)$ scanning in combination with computed tomography (CT) identified functionally active BAT depots in adult humans, which are more frequent in women than in men. Substantial FDG uptake into the adipose tissue in the supraclavicular and paraspinal regions was observed in adult human following mild cold exposure compared to the subjects kept at a warm 
temperature $\left(27^{\circ} \mathrm{C}\right)$. The amount of BAT was found to be inversely correlated with body-mass index suggesting the importance of BAT in regulating adult human metabolism.

BAT is also known to secrete various metabolism-improving factors, collectively called BATokines, that target various cell types. Several BATokines, including fibroblast growth factor 21 (FGF21), interleukin 6 (IL-6), growth differentiation factor 15 (GDF15), neuregulin 4 (Nrg4), bone morphogenic protein 8b (Bmp8b), and follistatin (Fst) amongst several others have been reported to serve as Batokines [1-4]. Morphological and gene expression data obtained from BAT transplantation studies revealed larger adipocyte size and reduced thermogenic gene expression compared to the endogenous BAT, suggesting that the beneficial effects of BAT transplantation could primarily be due to the secreted factors from the transplant [5]. Human pluripotent stem cell-derived brown adipocyte are reported to significantly improve glucose and lipid metabolism and prevent obesity [6,7]. Recent studies demonstrate the association of human BAT with lower blood glucose and triglyceride levels, higher HDL levels, and improved cardio-metabolic health [8]. Future retrospective studies are needed to understand the role of BAT in metabolic health and delineate the clinical and physiological significance of human BAT in the context of obesity-related cardio metabolic diseases. Besides the well-accepted view that BAT activation is beneficial in general, results of unfavorable outcomes from hyper-activation of BAT has also been reported in promoting atherosclerosis in animal models [9], cancer cachexia [10], and breast cancer cells in promoting cancer progression [11]. These findings, therefore, suggest that therapeutic interventions for the treatment of obesity-associated metabolic conditions using BAT activation should be carefully controlled and monitored.

\section{Imaging studies for human brown adipose tissue detection}

In spite of early reports of the presence of BAT in adult humans in 1972 [12], its physiological and clinical relevance was mostly ignored by the scientific and medical community. Three simultaneous studies published in the New England Journal of Medicine [13-15] reported the detection of adult human adipose tissue, using PET/CT scans, and their confirmation as BAT by molecular analyses of the 
adipose tissue biopsies. Considering the need of developing appropriate research protocols to identify depots of metabolic activities following BAT-activating interventions in human subjects, variety of imaging techniques have been used over the years. Since biopsies of human BAT have been exclusively restricted for ethical reasons and are limited mostly to cadavers or excised tissues obtained for the analysis of oncogenic markers, several biomedical imaging techniques over the years have allowed us to study the functional and morphological characteristics of BAT in vivo.

${ }^{18} \mathrm{~F}-\mathrm{FDG}-\mathrm{PET} / \mathrm{CT}$ is used as a gold standard for studying activated BAT in humans since 2009 despite its many limitations for identifying and quantifying inducible BAT [16]. The use of ionizing radiation is a major concern when applying PET imaging for BAT, especially in longitudinal studies with healthy human subject. This technique relies on glucose uptake, but stored energy in oxidative BAT generated from intracellular triglyceride hydrolysis serves as the main substrate for BAT oxidative metabolism [17]. Also, evidence for small amounts of glucose uptake by acute stimulation of $\beta 3$-adrenergic receptor ( $\beta 3$ AR) has been reported [18]. Therefore, probing oxidative metabolism or fatty acid uptake would be a more sensitive method for molecular imaging of BAT and assessment of its activity compared to FDGPET. Nevertheless, from a historical perspective, FDG-PET/CT remains the most widely used imaging study. Studies form the supraclavicular FDG uptake in cancer patients were amongst the first to provide evidence for BAT prevalence in adult human [19,20]. FDG-PET/CT imaging was capable of detecting higher iBAT levels associated with visceral adiposity. However, insensitivity of this method to detect inactive BAT in obese and metabolically unhealthy subjects presents a significant limitation of this method in a clinical setting.

Molecular resonance imaging (MRI) and magnetic resonance spectroscopy (MRS) methods does not use radiation and takes advantage of the morphological and functional information to differentiate BAT from white adipose tissues (WAT). MRI provides greater tissue contrast and adequate spatial resolution compared to other tomographic imaging techniques. MRI protocol, mostly used to differentiate between WAT and BAT and analyze BAT morphology, is based on the quantitation of water and fat content in the tissue. BAT water-fat composition in humans is primarily measured by using 
chemical shift-encoding water-fat imaging which are present in the MRI scanners and reported to show higher reproducibility in humans across all ages [21-25]. However, proper identification of BAT exclusively based on MRI fat fraction measurements remains challenging as cold exposure or adrenergic activation significantly change BAT lipid content and varies widely with BMI, age, external temperature and diet [12,26-27]. Heterogeneous mixture of BAT and WAT existing in the supraclavicular fossa of human BAT present another limitation of water-fat MRI technique. Relatively longer scan times often requiring sedation and use of anesthesia is another practical limitation to MRI. Numerous ongoing advances in imaging techniques and research protocols using improved tracers with significant improvement in sensitivity and specificity could provide accurate and reliable assessment of BAT depots as well their metabolic activation. Such advancement in imaging techniques would provide highly improved techniques to measure the mass and activity of human BAT in vivo and understand BAT physiology and its potential as a therapeutic target for the treatment of obesityassociated metabolic complications.

\section{Sexual dimorphisms in rodent and human thermogenic adipose tissue}

The prevalence of obesity and related metabolic diseases is rapidly increasing in both men and women. However, the clinical manifestations of these metabolic diseases significantly differ between the genders. Several retrospective studies over the years have indicated that the prevalence of BAT is higher in women than in men $[13,28]$. There is also some indication that the metabolic activity and BAT mass is higher in women subjects [28]. However, few studies found no significant difference in BAT prevalence between men and women [29,30]. In another study, van Marken Lichtenbelt et. al. reported that $95 \%$ of all young men possessed BAT, implying that it is less likely that women would have higher prevalence of BAT [14]. The anatomical distribution of BAT is similar in both women and men and mostly in the cervical, supraclavicular, axillary, paraspinal, mediastinal, and abdominal areas, of which supraclavicular regions are the most common location of active BAT detection with FGD-PET-CT [31]. In a diet-induced obesity model, female mice display higher vascularization of perigonadal WAT 
compared to the male mice [32]. It is possible that such gender differences in vascularization could exist in humans, and the sex hormones could differentially mediate the extent of adrenergic activation between men and women. Rodriguez-Cuenca et. al. reported that BAT from female rats are more sensitive to $\beta$-adrenergic stimulation [33]. Although elevated adrenergic responses to lipolysis are reported in women [34], the underlying differences in $\beta$-adrenergic receptor signaling between rat and humans could be significantly altered based on the presence of $\beta 1-A R$ in humans [35]. Female rats show increased abundance of UCP1 expression compared to males and display higher mitochondrial density [33]. Data from human studies, reported that women display higher cold sensation and may need to activate thermogenesis at higher temperatures compared to men [36]. In addition, female rats show higher protein expression levels of UCP1 and various other proteins involved in thermogenesis compared to male rats fed on high fat diet [37], supporting the view that rodents display higher BAT thermogenic capacity in females. In human studies, similar upregulated UCP1 gene expression were found in subcutaneous and perirenal WAT of females $[38,39]$.

A systematic global gene expression profile of more than 100 inbred mice show higher WAT UCP1 expression and its association with healthier phenotype in female mice [40]. On the other hand, UCP1 expression positively correlated with increased fat mass and insulin resistance in male mice. Collectively these reports support sexual differences in BAT prevalence and function.

\section{Aging-induced changes in beige and brown adipocytes}

Adipose tissue undergoes profound changes with aging in terms of its composition and distribution leading to metabolic alterations. This aging related adipose tissue dysfunction have severe impact on whole body energy homeostasis and often results in the progressive development of metabolic complications. It has been established that human BAT mass and activity decline with age. BAT formation starts during gestation where it is critical for thermogenesis in early phases of human life. Supraclavicular BAT is the major site of metabolically active BAT in childhood. BAT activity increases during adolescence and sexual maturation and decline with aging. Cold-stimulated BAT activity by 
FDG-PET/CT imaging is rarely detectable in living individuals over the age of sixty, although BAT mass may not change [41]. Significant aging-related decline of BAT activity and concomitant loss of UCP1 expression in rodents has also been reported in several studies, suggesting that gradual decline of BAT activity is common in both rodent and human [42].

Possible mechanisms involved during aging-related impairment of BAT development and function include loss of mitochondrial function, reduced sensitivity to sympathetic tone, alterations in brown adipose progenitor/stem cell function and changes in endocrine control of BAT formation. Reduced capacity of beige adipocyte formation, resulting from aging-induced changes in trophic factors in the adipose tissue, also contribute to the impairment of thermogenic function. Mitochondrial dysfunction has long been associated with several aging-related disorders, including obesity, type 2 diabetes, tumorigenesis, and neuronal diseases [43]. Increased mitochondrial DNA mutations and progressive decline in mitochondrial biogenesis are important contributors to human aging-associated adipose tissue dysfunction [44]. Age-associated impairment of the regenerative potential of brown adipose stem/progenitor cells could contribute to dysfunctional BAT adipocytes [43]. Defective differentiation ability of CD137 and TMEM26-expressing sub-population of WAT progenitor cells could also contribute to the loss of beige adipocyte during aging [45]. SirT1, a potent inducer of adipose browning, can significantly enhance beige adipocyte differentiation capability in elderly adipose-derived mesenchymal stem cell (AD-MSC) population [46]. The sympathetic nervous system (SNS) plays a central role in recruitment of brown adipocytes and its thermogenic activity through $\beta 3-A R$ stimulation [47]. SNS stimulation and BAT activation was lower in older lean men compared to the younger and obese men [48]. In addition, Yoneshiro et. al. reported that a single nucleotide polymorphisms in $\beta 3-A R$ and UCP1 contributed to aging-associated decline in BAT activity in humans [49], suggesting that aging-related decrease in SNS stimulation and sensitivity in older human may result in decreased ability to recruit and activate BAT.

Aging-associated hormonal changes also play a central role in regulating the thermogenic activity in human BAT. While sex hormones like estrogens and androgens positively regulate BAT activity and 
function, glucocorticoids such as dexamethasone reduce catecholamine-induced expression of UCP1 $[28,50]$. Relatively higher levels of sex hormones in the young counteract the generally inhibitory effects of glucocorticoids in BAT. Because of aging, sex hormone levels significantly decline without significant alteration in glucocorticoid levels resulting in reduced energy expenditure and loss of BAT activity. Aging-associated decrease in thyroid hormone $(\mathrm{TH})$, known regulators of white adipose browning, has recently been demonstrated in murine WAT [51,52]. In light of these reports, future human studies are needed to develop effective pharmacological interventions aimed at preventing aging-associated decline in BAT activity.

\section{Molecular gene signature of brown and beige adipocytes in rodents and humans}

Various cell-sorting and lineage-tracing studies in rodents have demonstrated that different types of adipose cells have distinct set of molecular markers and arise from distinct pools of progenitors [45,5355]. Classical brown adipocytes present in BAT originate from a population of dermomyotome expressing Myf5, Pax7 and engrailed 1 [56,57]. Analyses of global gene expression profile of interscapular BAT demonstrate that these brown adipocyte precursors resemble the gene signature with skeletal muscle cells that also express Myf5-positive precursor population [58]. Data from proteomics analysis of interscapular BAT and skeletal muscle further confirmed strong similarity in the protein levels [59]. Classical BAT is reported to selectively express high levels of Lhx8, Zic1, Eva1 (Mpzl2) and Epsti 1, although there are recent reports that suggest that Lhx8 could also be present in human beige adipocyte [60]. Several additional markers including Ebf2, Pdk4, Hsbp7, Oplah, Fbxo3, Slc29a1, and Acot2 were found to be highly enriched in interscapular BAT obtained from 129SVE mice [45]. Recently, Prex1, a positive regulator of Ucp1 gene expression was found to be another BAT marker present in the brown adipose precursor cells [61]. Since no published studies has reported upregulation of Prex1 levels in beige adipocytes, it could be considered as a unique BAT marker.

Beige adipocytes, on the other hand arise from a non-Myf5 lineage [62], although there are several recent reports that beige adipocytes in WAT depots may have multiple origins [27,54]. Beige adipocytes, 
in general, are selectively enriched in Tmem26, CD137, CD40 and Tbx1. These markers are expressed in high levels in epididymal adipose depots compared to the interscapular BAT following cold exposure or $\beta$-adrenergic stimulation [45]. Several additional beige-selective genes including Klh113, Ear2, Sp100, and Slc27a, were reported in the same study following analysis of gene expression in inguinal WAT and BAT. Gene expression and histological analysis of human BAT that resemble beige adipocytes identified Cited1, Hoxc8, Hoxc9 and Shox2 as beige-selective genes [60,63]. Differences in the levels of microRNA (miRNA) between beige and BAT has also been identified. Mir193b-365 cluster was found to be a key regulator of BAT development [64]. Additional miRNAs required for the maintenance and differentiation of BAT, including miRNA182 and miRNA 203 were identified following comparative miRNA expression profiling of mouse and human BAT $[65,66]$. Some recently identified miRNA including miRNA196b and miRNA26 are reported to positively and negatively regulate brown adipogenesis of white fat progenitor cells respectively $[67,68]$.

Transcriptional analyses of human BAT isolated from multiple adipose depots display molecular signatures that closely resemble beige adipose-selective genes. The authors found that common beige adipose markers including HOXC8, HOXC9, CITED1, CD137, TMEM26 and TBX1 were highly expressed in all human BAT [60]. Molecular characterization of human perirenal BAT depot show higher expression of number of genes HMGCS2, CKMT1A/1B, KCNK3 and PGC1a in BAT compared to the WAT [69]. They also identified high levels of BAT-associated genes including ACOT11, PYGM and FABP3 in the perirenal adipose tissue, which display high correlation with UCP1 and to each other. Recent studies in humans indicate high levels of UCP1-immunopositive adipocytes in the anatomically defined neck fat from the supraclavicular and spinal cord regions of adult human subjects and display molecular signatures of classical BAT, including high expression levels of genes involved in mitochondrial biogenesis and thermogenesis including UCP1, PGC1 and DIO2 [70]. The degree of correlation of the genes assessed by hierarchical clustering in deep neck tissues with highest UCP1 expression show increased levels of UCP1, ZIC1 and LHX8. Some genes previously designated as markers of BAT lineage in mouse including EBF3, MPZL2 and FBXO31 did not have elevated 
expression in the deeper human neck depot or associate closely with UCP1 expression. On the other hand, expression levels of CD137, TMEM26, TBX1, EVA1 and EBF3 does not differ between subcutaneous and deeper neck adipose depots. Since adipose tissue depots are highly heterogeneous and inter-subject differences could significantly affect the thermogenic potential, clonal cell lines from human neck fat were generated and characterized for their adipogenic and metabolic functions in vitro and in vivo after transplantation into immune-deficient nude mice [61]. Using UCP1 reporter system, the authors were able to reveal two general categories of genes in preadipocytes with enhanced capability to regulate late stage thermogenic differentiation program. PREX1, CTTNBP2, ACTC1 and SSTR1 genes were identified in the first category as positive regulators with enhanced thermogenic capacity. On the other hand, in the second category, DMRAT1, EDRNRB, FAT1 and PTPRB were reported to have negative correlation with UCP1-luciferase levels [61]. Zuriaga et. al. performed comparative gene analyses of browning gene expression profiles in the subcutaneous and visceral WAT of obese mice and human subjects and reported a pattern that is opposite to what is observed in mice [71]. Obese mice displayed higher expression of typical browning markers UCP1, Cidea and Prdm16 and beige markers Tbx1 and P2rx5 compared to the epididymal WAT. However, in obese humans, visceral WAT show higher expression of UCP1 and several other adipose browning (CIDEA, PRDM16, TBX1 and P2RX5) and mitochondrial (COX8B, PGC1 $\alpha$, ATP5A, and NDUFA1) genes compared to the subcutaneous adipose depots [71]. These findings suggest increased browning capacity of human visceral WAT compared to the subcutaneous WAT.

\section{Cold exposure and activation of sympathetic nervous system}

In earlier experiments, appearance of brown-like adipocytes in the parametrial fat depots were reported in mice following severe cold exposure [72]. Subsequent studies over in murine models over the years clearly established a role for cold-induced BAT activation as a physiological response to acute or mild cold exposure for maintaining thermal demands through non-shivering thermogenesis (NST) $[73,74]$. 
Cold acclimation led to the activation of PGC1a and induction of UCP1-PRDM16 signaling cascade in murine studies [75].

Higher prevalence of BAT during cold season and reported seasonal variability in human subcutaneous and retroperitoneal WAT strongly suggest that cold exposure should promote adipose browning and activation of BAT characteristics in humans $[75,76]$. Cold exposure is the most common method for BAT activation in humans via the activation of NST [77], that is achieved either by reducing the ambient room temperature between $16-19^{\circ} \mathrm{C}[15,78]$ or with cold water-infused jackets $[79,80]$. Cold acclimation increases BAT oxidative capacity, which correlated with a reduction of shivering thermogenesis $[77,81]$. Cold adaptation in BAT is also associated with mitochondrial remodeling and vascularization for adaptive thermogenesis [74] and fatty acid oxidation through UCP1 during high metabolic demands [82].

Significant increase in BAT activity and NST was reported in humans following 10-day acclimation protocols [77]. Respiratory measurements in skeletal muscle suggested no significant contribution from mitochondrial uncoupling towards increased NST. The authors did not find any sex differences in BAT prevalence and activities between men and women. There was no significant increase in adipose browning markers in subcutaneous WAT, suggesting that a stronger cold stimulation or prolonged period of cold acclimation may be needed for the upregulation of general browning markers. In another human study Ouellet et. al. reported that BAT oxidative metabolism significantly contributed to increased energy expenditure, glucose uptake, and non-esterified fatty acid (NEFA) turnover in healthy men during acute cold exposure [79]. Similar increase in glucose uptake following activation of BAT by cold exposure and insulin was reported in another study [83], suggesting that BAT activation leads to clearance of plasma glucose. Analysis of glucose metabolism in individuals with (BAT+) or without (BAT-) BAT under cold exposure showed increased whole-body glucose in the fasted and insulin stimulated BAT+ individuals. This only suggests that BAT can indeed significantly influence systemic glucose metabolism in humans [84] and may represent a novel target to combat hyperglycemia. In addition, it was observed that mild daily cold exposure $\left(17^{\circ} \mathrm{C}\right)$ for 6 weeks induces BAT recruitment in 
healthy human subjects with low BAT activity independently of age and fat-free mass [85], suggesting that cold-induced recruitment of BAT could serve as a viable means to decreased fat mass in aging population.

Sympathetic nervous system plays an important role in the physiological regulation of BAT activity, mediated mainly via the activation of beta 3-adrenergic receptor ( $\beta 3-A R$ ) present in brown adipocytes. Chronic treatment of rat with selective $\beta 3-A R$ agonist CL316243 significantly increased energy expenditure and body temperature, these effects were associated with 3-4 fold increase in Ucp1 expression in interscapular BAT [86]. In this study, CL316243 promoted not only BAT mitochondrial biogenesis, but it also inhibited the development of WAT hyperplasia during diet-induced obesity. Treatment of male mice with CL316243 led to significant upregulation of Ucp1 gene expression in retroperitoneal adipose tissue and correlated with weight loss [87]. These studies conducted in rodents support the view that activation of $\beta 3-A R$ with CL316243 is an effect method to induce BAT activity and stimulate beige cell phenotype in typical WAT. Long-term sympathetic regulation of thermogenic BAT activity and its association with reduced body weight in catecholamine-producing human pheochromocytoma patients is well known. Administration of $\beta 3-A R$ agonist in human subjects for 4-8 weeks significantly improved insulin sensitivity and lipid profiles without any change in body weight $[88,89]$. More recently, treatment of human subjects with a single high dose of $\beta 3-A R$ agonist mirabegron increased BAT ${ }^{18} \mathrm{~F}-\mathrm{FDG}$ uptake, and energy expenditure [90], although $\beta 2-\mathrm{AR}$ and $\beta 1-\mathrm{AR}$ are more highly expressed in human BAT [91]. Mixed AR agonist ephedrine also increased ${ }^{18} \mathrm{~F}-\mathrm{FDG}$ uptake in BAT in lean but not obese subjects at room temperature [92]. However, side-effects associated with increased heart rate and blood pressure induced by these compounds significantly limit the potential use of this therapeutic approach $[90,92,93]$.

\section{WAT browning factors}

Due to the relatively lower amount of BAT present in adult humans, WAT has remained the major focus of targeting against obesity and related metabolic diseases. Even though WAT is known to have fewer 
numbers of mitochondria with larger lipid droplets, manipulation of WAT to brown-like phenotype with increased thermogenic capacity through the process called "adipose browning" is being explored as a major therapeutic strategy. Several browning agents have been identified in recent years in animal studies; some of which are currently being investigated in humans [94,95]. Safe activation of adipose browning requires identification of specific molecular pathways involved in WAT browning. Fibroblast growth factor 21 (FGF21), expressed mainly in liver [96], is also present in BAT [97], and regulates energy metabolism by promoting adipose browning and lipoprotein catabolism $[98,99]$. Therapeutic potential of FGF21 analogs have been explored in obese human subjects with type 2 diabetes recently $[100,101]$. These analogs reduced body weight and improved circulating lipids but failed to improve glucose levels. These studies did not measure BAT activity or WAT browning. Additional endocrine factors including natriuretic peptides, prostaglandins and $\beta$-aminoisobutyric acid (BAIBA) and thyroid hormones (TH) are known to influence WAT differentiation and browning [102-104]. Several members of transforming growth factor beta (TGF- $\beta$ ) superfamily including bone morphogenic proteins (BMP) such as BMP7, BMP8b and BMP4, regulate various aspects of WAT browning and BAT differentiation in rodents] as well as in human adipocyte cell models [105-107]. Additional modulators of TGF- $\beta$ signaling pathway, including follistatin (Fst) and inhibitors of myostatin (Mst) have been recently reported to upregulate key thermogenic markers, increase mitochondrial biogenesis, and promote WAT browning [108-110]. Improved insulin sensitivity and reduced lipogenic effects of Gleevec was associated with increased WAT browning and energy expenditure. These beneficial effects of Gleevec was blocked by inhibition of PPARY phosphorylation, suggesting a critical role for PPARY-mediated signaling pathway during the process [111]. Thiazolidinediones (TZDs), known agonists of PPARY used as insulin sensitizing drugs for the treatment of $\mathrm{T} 2 \mathrm{D}$, promote adipose browning both in vivo and in vitro $[112,113]$. Another antidiabetic agent, liraglutide that acts as an agonist of glucagon-like peptide-1 (GLP-1) receptor, significantly reduced weight gain in obese subjects [114]. Although GLP-1 mediated weight loss results were mainly due to appetite suppression, increased energy expenditure is recently reported in liraglutide-treated obese human patients with type-2 diabetes [115]. The bile acid 
chenodeoxycholic acid (CDCA) increase BAT activity in both mice and humans $[116,117]$. Several plant-derived products influence adipocyte metabolic characteristics. Natural plant polyphenol such as resveratrol and butein increase energy expenditure and promote thermogenesis by induction of Prdm16, Ucp1, and Pgc1a [118]. Another plant based compound capsaicin stimulate thermogenic Ucp1 and Bmp8b genes and trigger WAT browning by stimulating SirT1-dependent acetylation of PPARY and Prdm16 [119]. Another study in humans using a single dose of capsinoids demonstrate increased energy expenditure selectively in people with metabolically active BAT, suggesting the beneficial effects of capsinoids-induced WAT browning in both human and mice [120]. Lactate, an important metabolic intermediate upregulate Ucp1 expression and induce WAT browning by regulating PPARY signaling [121].

\section{Exercise}

Exercise is an effective way to prevent and treat obesity and related metabolic diseases. Although adaptation to skeletal muscle is most widely studied, it also significantly influences the phenotype and functions of adipose tissues. Exercise increases whole body energy expenditure and several metabolic adaptations to WAT through the process of adipose beiging mainly in subcutaneous WAT (scWAT). Exercise-induced upregulation of thermogenic genes such as Prdm16 and Ucp1 in scWAT and increase the presence of multilocular lipid droplets in adipocytes [122,123]. PGC1- $\alpha$, a muscle-derived myokine, seems to be an important mediator of the exercise-induced browning process that influences myogenesis as well as mitochondrial oxidative phosphorylation [124]. Irisin, another browning agent that works through the PGC1- $\alpha$ pathway, is secreted from skeletal muscle and upregulates UCP1 expression in scWAT, increases energy expenditure and protects against diet-induced weight gain in mice [124]. Irisin induced adipose browning of white adipocytes in vitro and its circulating levels are increased in humans following exercise and cold exposure [124,125]. However, human data obtained from several laboratories studying the effect of exercise on irisin levels, are inconsistent and raise doubts about the role of irisin in mediating exercise effects $[126,127]$. Although direct effects of irisin 
administration in humans has not yet been conducted, in some human studies plasma irisin levels were found to be higher in obese humans and its levels correlate positively with plasma FFA $[128,129]$. In light of these controversial reports, the beneficial role of irisin for treating or managing obesity has been questioned. Several other exercise-induced factors, including FGF21, IL-6, follistatin, myostatin, meteorin-like1 (Metrnl), lactate, BAIBA and brain-derived neurotrophic factor (BDNF) have been associated with WAT browning [121,130-134]. Exercise-induced changes in WAT include increased mitochondrial biogenesis and glucose uptake, decreased lipid content and inflammation [135,136]. Although such adaptations to exercise in multiple tissues are known in both rodents and humans, it is important to note that more investigations are needed to clearly establish exercise-induced adipose browning and on whole-body metabolic health in human subjects.

\section{MicroRNAs in browning}

Micro RNAs (miRNAs) are single stranded small non-coding RNAs (20-24 nucleotides) that regulate a wide spectrum of biological processes implicated in cellular metabolism and pathology of a variety of diseases. In recent years, several miRNAs were identified that play important roles in regulating beige and brown adipocyte differentiation and function $[137,138]$. Delineating the regulatory mechanisms of miRNA action has great potential to provide therapeutic approaches to combat obesity and related metabolic diseases by increasing overall energy expenditure. Several miRNAs, including miRNA328, miRNA193b-365, miRNA203, miRNA182, miRNA 129, miRNA106b, and miRNA93b have been identified that specifically regulate brown adipogenesis either by promoting or inhibiting BAT thermogenic program [137]. Inhibition of miRNA182 or miRNA203 results in significant reduction of various BAT markers, including UCP1, PGC1 $\alpha$, and Cidea as well as downregulation of genes involved in electron transport chain and oxidative phosphorylation [139]. However, there was no change in the levels of classical adipogenic markers PPARY and FABP4 in this study. Interestingly, platelet-derived growth factor alpha (Pdgrfa) and insulin-induced gene 1 (Insig1) were identified as targets of miRNA182 or miRNA203. The miRNA193b-365 cluster is highly expressed in BAT and is reported to promote 
brown fat differentiation by inhibiting runt-related transcription factor 1 translocated to 1 (Runx1t1) [140]. The function of these miRNAs is still not confirmed as in vivo studies show no change in BAT morphology and function in absence of this cluster. The levels of miRNA 328 in mice on high fat diet was decreased in BAT and found to be upregulated during brown adipocyte differentiation [141]. On the other hand, decreased expression of several thermogenic genes including Ucp1, Prdm16, Pgc1a and Cidea were reported after inhibition of miRNA328 in this study. In addition, overexpression of miRNA328 in brown adipocytes significantly inhibited Bace 1 protein that decreases energy expenditure and UCP1 expression [142]. MiRNA106b-93 cluster is identified as negative regulators of BAT differentiation and their levels are found to be increased in obese mouse BAT [143]. Inhibition of miRNA 106-93 induced expression of several BAT markers, including UCP1, PRDM16, PGC1a and Cidea [143]. These findings, therefore, suggest an important role for miRNA106b-93 cluster in BAT energy homeostasis.

In addition, several miRNAs play significant role in regulating beige adipocyte development and function. Better understanding of the key beige-specific miRNAs and their regulation would be critical for developing efficient therapeutic approaches to increase cellular energy expenditure and slow down the progression of obesity. miRNA196a plays an important role in browning of white adipose progenitor cells with increased expression of several brown adipogenic genes such as C/ebpa, Prdm16, Ucp1, and Pgc1a [67]. miRNA196a induce WAT beiging in human by direct binding and suppression of homeobox C8 (Hoxc8), a known repressor of C/EBP $\beta$. Overexpression of miRNA196a improved glucose metabolism and resistance to diet-induced obesity in mice [67]. MiRNA26 family (miRNA26a and miRNA26b) has been identified as important regulator of white and beige adipocyte differentiation in human [144]. miRNA26 level is induced in WAT following cold exposure and mimics of miRNA26a/b promote adipose browning and mitochondrial phenotype by upregulating the expression of UCP1, PGC1a, as well as aP2. Mechanistically, the adipose browning effects of the miRNA26 family are mediated by direct targeting of ADAM17 [144]. MiRNA125-5p has been identified as a negative regulator of adipose browning. Its expression level is higher in WAT compared to BAT and decreases 
during browning [145]. Beige adipocyte formation and mitochondrial biogenesis is significantly inhibited following injection of miRNA125-5p into WAT [145].

In addition, several miRNAs have been identified that play important roles in regulating both BAT and WAT browning. MiRNA30 family members promote development of beige and thermogenesis [146]. Levels of miRNA30 is higher in BAT compared to WAT. Activation of $\beta$-AR signaling or cold exposure upregulate expression of key thermogenic (UCP1 and Cidea) and mitochondrial biogenesis genes in brown adipocytes. Inhibition of miRNA30b/c levels in vivo results in downregulation of UCP1 expression and reduction of BAT mitochondrial respiration by its direct action on targeting of receptor-interacting protein 140 (RIP140) [147], suggesting that miRNA30b/c positively regulates beige adipocyte development as well as BAT thermogenesis. MiRNA455 was identified as a key regulator of brown adipogenesis in multipotent mesenchymal cells. MiRNA455 levels are induced by cold exposure and BMP7 treatment [148]. Inhibition of miRNA455 results in suppression of brown adipose differentiation. In addition, adipose-specific transgenic mice overexpressing miRNA455 display significant WAT browning, increased insulin sensitivity and glucose tolerance and resistance to diet-induced increase in body weight [148]. MiRNA378 has been identified as the only miRNA that can regulate brown and white adipocyte in opposing fashion. Adipose-specific overexpression of miRNA378 increased BAT mass and brown adipogenesis but show decreased WAT mass and cell size, and reduces diet-induced obesity in ob/ob mice [149]. These dual effects of miRNA378 in promoting brown adipogenesis but blunting WAT beige adipogenesis is caused by direct targeting of $\mathrm{Pde} 1 \mathrm{~b}$, a phosphodiesterase that causes reduction in cAMP levels [150]. Further studies are needed to clearly understand the complex mechanism in order to develop suitable miRNA-based therapeutic approaches for the treatment of obesity and related metabolic disorders.

\section{Challenges and potential concerns with BAT activation as a therapeutic strategy to combat obesity}


Therapeutic targeting of BAT for obesity was envisioned in late 1970s based on rodent studies suggesting that BAT may be the major site for thermogenesis in response to both cold and diet $[151,152]$. Unequivocal discovery of active and functional BAT in healthy human subjects confirmed the expression of thermogenic UCP1 and its energy dissipating capacity in humans. Increasing energy expenditure by cold exposure and BAT activation holds great potential to combat obesity-related metabolic complications; however, there are notable concerns with this approach that must be carefully evaluated. While there are many similarities between mouse and human BAT, notable morphological and anatomical differences also exist. In order to translate the significance of rodent studies in humans, it is important to generate proof of concept studies in humans for successful clinical outcomes. Activation of $\beta-A R$ signaling needed for BAT thermogenesis is mediated via $\beta 3-A R$ in rodents. Recent studies in human revealed that $\beta 2-A R$ is the predominant adrenergic receptor [91], suggesting that selective BAT activation in humans may be difficult to achieve and requires activation of another $\beta-A R$ subtype. Targeting thermogenic BAT activation could result in significantly increased heart rate as increased energy expenditure requires increased demand for oxygen. Chronic BAT activation from $\beta 3$ AR agonists or thyroid hormone replacement may cause tachycardia and hypertension resulting in unwanted cardiovascular side effects such as stroke or myocardial infarction [153,154]. Another potential problem during pharmacological activation of BAT could result from dissipation of heat. Weight loss medication 2,4-dinitrophenol (DNP) that works by uncoupling of oxidative phosphorylation, caused hyperthermia and could be fatal at higher doses [155]. Although it is unlikely that selective pharmacological approaches to activate thermogenesis will have severe thermal stress at low doses, caution is warranted to avoid unwanted off target-effects. In addition, the impact of increased energy expenditure could lead to compensatory hyperphagic response during cold exposure [156]. However, data accumulated over the past decade indicates that pharmacotherapy approaches to activate BAT via $\beta 3-A R$ agonists or administration of various thermogenic food ingredients lead to increased food intake [157]. 
Several recent studies also suggest that BAT activation could be harmful. Cold-induced BAT hyper activation in ApoE-null mice resulted in exacerbation of atherosclerotic plaques and its stability [9]. This cold-induced lipolysis in ApoE-null mice was food intake-independent and significantly increased LDL remnants. Increased levels of inflammatory cells and plaque-associated micro vessels were detected in cold-acclimated mice. Deletion of UCP1 in BAT protected these ApoE-null mice from development of cold-induced atherosclerotic lesions. Adverse effects of BAT activation is also reported in the development of cancer cachexia [158]. IL6 and GDF15, two BAT-secreted factors are key mediators of cancer-induced cachexia $[158,159]$. Using xenotransplantation models that use human breast cancer cells as well as fresh human tumor tissues transplanted into nude mice, Singh et. al. provided evidence for the involvement of beige and brown adipose cells during the progression of breast cancer progression [11]. In this study, selective enrichment of BAT-selective genes were observed in the tumor as well as host cells, and depletion of UCP1 and Myf5-positive population resulted in significantly reduced tumor size. It is not known whether BAT plays important role in the progression of other cancers. These findings, therefore, clearly indicate that BAT-based therapeutic drug development for the treatment of obesity and related diseases should be carefully assessed to avoid unwanted adverse effects.

\section{Conclusions}

Since the demonstration of active and functional BAT in adult human subjects, activation of adipose browning characteristics to dissipate excess stored energy has shown great promise to combat obesityassociated comorbidities including type 2 diabetes, insulin resistance, hyperlipidemia and cardiovascular diseases. Identification of novel compounds that can promote adipose browning and understand the molecular signaling mechanism involved during the process will provide new insights for therapeutic drug development targeted against obesity-related diseases. Recent studies have also provided ample evidence that BAT also plays an important role in the regulation of systemic and peripheral glucose homeostasis by functioning as a metabolic sink for glucose and triglycerides. 
Number of pharmacological agents have been tested to activate adipose browning characteristics (Table 1); however, these attempts have mostly failed, partially due to modest efficiency and adverse side effects including elevated blood pressure (92). It is also important to develop new techniques to assess the thermogenic capacity of novel compounds in adult humans as FDG-PET/CT scans do not accurately measure total BAT mass. Other currently available devices are not sensitive enough to accurately detect UCP1-expressing subcutaneous WAT and other adjacent tissues. Recent studies demonstrating the therapeutic potential of transplanted BAT in rodent studies to improve weight loss and improved insulin sensitivity has not been explored in human subjects. The effectiveness and clinical relevance of BAT activation and recruitment in human subjects needs to be further explored in details. 
Author Contributions: Conceptualizations, R.S. and S.P.; Writing -original draft preparation, R.S., A.B., G.D.; Schematics and Table creation, A.B., G.D., Review and editing-R.S., S.P. All authors have read, revised and approved the final manuscript.

Funding: This work was supported by TRDRP grant T31IP1551 (RS), NIH grants SC1CA232319 (SP), UHI NIMHD S21MD000103, and Accelerating Excellence in Translational Sciences (AXIS) Center U54MD007598 to Charles R Drew University of Medicine and Science.

Conflicts of interest: The authors declare no conflict of interest. 


\section{References:}

1. Hondares, E.; Iglesias, R.; Giralt, A.; Gonzalez, F.J.; Giralt, M.; Mampel, T.; Villarroya, F. Thermogenic Activation Induces FGF21 Expression and Release in Brown Adipose Tissue. Journal of Biological Chemistry 2011, 286, 12983-12990, doi:10.1074/jbc.M110.215889.

2. Chartoumpekis, D.V.; Habeos, I.G.; Ziros, P.G.; Psyrogiannis, A.I.; Kyriazopoulou, V.E.; Papavassiliou, A.G. Brown Adipose Tissue Responds to Cold and Adrenergic Stimulation by Induction of FGF21. Mol Med 2011, 17, 736-740, doi:10.2119/molmed.2011.00075.

3. Oka, M.; Kobayashi, N.; Matsumura, K.; Nishio, M.; Nakano, K.; Okamura, T.; Okochi, H.; Minamisawa, T.; Shiba, K.; Saeki, K. New Role for Growth/Differentiation Factor 15 in the Survival of Transplanted Brown Adipose Tissues in Cooperation with Interleukin-6. Cells 2020, 9, 1365, doi:10.3390/cells9061365.

4. Whittle, A.J.; Carobbio, S.; Martins, L.; Slawik, M.; Hondares, E.; Vázquez, M.J.; Morgan, D.; Csikasz, R.I.; Gallego, R.; Rodriguez-Cuenca, S.; et al. BMP8B Increases Brown Adipose Tissue Thermogenesis through Both Central and Peripheral Actions. Cell 2012, 149, 871-885, doi:10.1016/i.cell.2012.02.066.

5. Liu, X.; Zheng, Z.; Zhu, X.; Meng, M.; Li, L.; Shen, Y.; Chi, Q.; Wang, D.; Zhang, Z.; Li, C.; et al. Brown Adipose Tissue Transplantation Improves Whole-Body Energy Metabolism. Cell Res 2013, 23, 851-854, doi:10.1038/cr.2013.64.

6. Stanford, K.I.; Middelbeek, R.J.W.; Townsend, K.L.; An, D.; Nygaard, E.B.; Hitchcox, K.M.; Markan, K.R.; Nakano, K.; Hirshman, M.F.; Tseng, Y.-H.; et al. Brown Adipose Tissue Regulates Glucose Homeostasis and Insulin Sensitivity. J. Clin. Invest. 2013, 123, 215-223, doi:10.1172/JCl62308.

7. Nishio, M.; Yoneshiro, T.; Nakahara, M.; Suzuki, S.; Saeki, K.; Hasegawa, M.; Kawai, Y.; Akutsu, H.; Umezawa, A.; Yasuda, K.; et al. Production of Functional Classical Brown Adipocytes from Human Pluripotent Stem Cells Using Specific Hemopoietin Cocktail without Gene Transfer. Cell Metabolism 2012, 16, 394-406, doi:10.1016/j.cmet.2012.08.001.

8. Becher, T.; Palanisamy, S.; Kramer, D.J.; Eljalby, M.; Marx, S.J.; Wibmer, A.G.; Butler, S.D.; Jiang, C.S.; Vaughan, R.; Schöder, H.; et al. Brown Adipose Tissue Is Associated with Cardiometabolic Health. Nat Med 2021, 27, 58-65, doi:10.1038/s41591-020-1126-7.

9. Dong, M.; Yang, X.; Lim, S.; Cao, Z.; Honek, J.; Lu, H.; Zhang, C.; Seki, T.; Hosaka, K.; Wahlberg, E.; et al. Cold Exposure Promotes Atherosclerotic Plaque Growth and Instability via UCP1Dependent Lipolysis. Cell Metabolism 2013, 18, 118-129, doi:10.1016/i.cmet.2013.06.003.

10. Petruzzelli, M.; Wagner, E.F. Mechanisms of Metabolic Dysfunction in Cancer-Associated Cachexia. Genes Dev. 2016, 30, 489-501, doi:10.1101/gad.276733.115.

11. Singh, R.; Parveen, M.; Basgen, J.M.; Fazel, S.; Meshesha, M.F.; Thames, E.C.; Moore, B.; Martinez, L.; Howard, C.B.; Vergnes, L.; et al. Increased Expression of Beige/Brown Adipose Markers from Host and Breast Cancer Cells Influence Xenograft Formation in Mice. Mol Cancer Res 2016, 14, 78-92, doi:10.1158/1541-7786.MCR-15-0151.

12. Heaton, J.M. The Distribution of Brown Adipose Tissue in the Human. J Anat 1972, 112, 35-39.

13. Cypess, A.M.; Lehman, S.; Williams, G.; Tal, I.; Rodman, D.; Goldfine, A.B.; Kuo, F.C.; Palmer, E.L.; Tseng, Y.-H.; Doria, A.; et al. Identification and Importance of Brown Adipose Tissue in Adult Humans. N Engl J Med 2009, 360, 1509-1517, doi:10.1056/NEJMoa0810780.

14. van Marken Lichtenbelt, W.D.; Vanhommerig, J.W.; Smulders, N.M.; Drossaerts, J.M.A.F.L.; Kemerink, G.J.; Bouvy, N.D.; Schrauwen, P.; Teule, G.J.J. Cold-Activated Brown Adipose Tissue in Healthy Men. N Engl J Med 2009, 360, 1500-1508, doi:10.1056/NEJMoa0808718.

15. Virtanen, K.A.; Lidell, M.E.; Orava, J.; Heglind, M.; Westergren, R.; Niemi, T.; Taittonen, M.; Laine, J.; Savisto, N.-J.; Enerbäck, S.; et al. Functional Brown Adipose Tissue in Healthy Adults. N Engl J Med 2009, 360, 1518-1525, doi:10.1056/NEJMoa0808949. 
16. Sampath, S.C.; Sampath, S.C.; Bredella, M.A.; Cypess, A.M.; Torriani, M. Imaging of Brown Adipose Tissue: State of the Art. Radiology 2016, 280, 4-19, doi:10.1148/radiol.2016150390.

17. Ma, S.W.Y.; Foster, D.O. Uptake of Glucose and Release of Fatty Acids and Glycerol by Rat Brown Adipose Tissue in Vivo. Can. J. Physiol. Pharmacol. 1986, 64, 609-614, doi:10.1139/y86101.

18. Olsen, J.M.; Sato, M.; Dallner, O.S.; Sandström, A.L.; Pisani, D.F.; Chambard, J.-C.; Amri, E.-Z.; Hutchinson, D.S.; Bengtsson, T. Glucose Uptake in Brown Fat Cells Is Dependent on MTOR Complex 2-Promoted GLUT1 Translocation. Journal of Cell Biology 2014, 207, 365-374, doi:10.1083/icb.201403080.

19. Cohade, C.; Osman, M.; Pannu, H.K.; Wahl, R.L. Uptake in Supraclavicular Area Fat ("USA-Fat”): Description on 18F-FDG PET/CT. J Nucl Med 2003, 44, 170-176.

20. Hany, T.F.; Gharehpapagh, E.; Kamel, E.M.; Buck, A.; Himms-Hagen, J.; von Schulthess, G.K. Brown Adipose Tissue: A Factor to Consider in Symmetrical Tracer Uptake in the Neck and Upper Chest Region. Eur J Nucl Med 2002, 29, 1393-1398, doi:10.1007/s00259-002-0902-6.

21. Hu, H.H.; Tovar, J.P.; Pavlova, Z.; Smith, M.L.; Gilsanz, V. Unequivocal Identification of Brown Adipose Tissue in a Human Infant. J. Magn. Reson. Imaging 2012, 35, 938-942, doi:10.1002/jmri.23531.

22. Hu, H.H.; Wu, T.-W.; Yin, L.; Kim, M.S.; Chia, J.M.; Perkins, T.G.; Gilsanz, V. MRI Detection of Brown Adipose Tissue with Low Fat Content in Newborns with Hypothermia. Magnetic Resonance Imaging 2014, 32, 107-117, doi:10.1016/j.mri.2013.10.003.

23. Hu, H.H.; Yin, L.; Aggabao, P.C.; Perkins, T.G.; Chia, J.M.; Gilsanz, V. Comparison of Brown and White Adipose Tissues in Infants and Children with Chemical-Shift-Encoded Water-Fat MRI: BAT and WAT in Infants and Children. J. Magn. Reson. Imaging 2013, 38, 885-896, doi:10.1002/imri.24053.

24. Iris Chen, Y.-C.; Cypess, A.M.; Chen, Y.-C.; Palmer, M.; Kolodny, G.; Kahn, C.R.; Kwong, K.K. Measurement of Human Brown Adipose Tissue Volume and Activity Using Anatomic MR Imaging and Functional MR Imaging. J Nucl Med 2013, 54, 1584-1587, doi:10.2967/jnumed.112.117275.

25. Franz, D.; Weidlich, D.; Freitag, F.; Holzapfel, C.; Drabsch, T.; Baum, T.; Eggers, H.; Witte, A.; Rummeny, E.J.; Hauner, H.; et al. Association of Proton Density Fat Fraction in Adipose Tissue with Imaging-Based and Anthropometric Obesity Markers in Adults. Int J Obes 2018, 42, 175182, doi:10.1038/ijo.2017.194.

26. Muzik, O.; Mangner, T.J.; Leonard, W.R.; Kumar, A.; Janisse, J.; Granneman, J.G. 150 PET Measurement of Blood Flow and Oxygen Consumption in Cold-Activated Human Brown Fat. $J$ Nucl Med 2013, 54, 523-531, doi:10.2967/jnumed.112.111336.

27. Frontini, A.; Cinti, S. Distribution and Development of Brown Adipocytes in the Murine and Human Adipose Organ. Cell Metabolism 2010, 11, 253-256, doi:10.1016/..cmet.2010.03.004.

28. Pfannenberg, C.; Werner, M.K.; Ripkens, S.; Stef, I.; Deckert, A.; Schmadl, M.; Reimold, M.; Haring, H.-U.; Claussen, C.D.; Stefan, N. Impact of Age on the Relationships of Brown Adipose Tissue With Sex and Adiposity in Humans. Diabetes 2010, 59, 1789-1793, doi:10.2337/db100004.

29. Saito, M.; Okamatsu-Ogura, Y.; Matsushita, M.; Watanabe, K.; Yoneshiro, T.; Nio-Kobayashi, J.; Iwanaga, T.; Miyagawa, M.; Kameya, T.; Nakada, K.; et al. High Incidence of Metabolically Active Brown Adipose Tissue in Healthy Adult Humans: Effects of Cold Exposure and Adiposity. Diabetes 2009, 58, 1526-1531, doi:10.2337/db09-0530.

30. Ouellet, V.; Routhier-Labadie, A.; Bellemare, W.; Lakhal-Chaieb, L.; Turcotte, E.; Carpentier, A.C.; Richard, D. Outdoor Temperature, Age, Sex, Body Mass Index, and Diabetic Status Determine the Prevalence, Mass, and Glucose-Uptake Activity of 18F-FDG-Detected BAT in Humans. The Journal of Clinical Endocrinology \& Metabolism 2011, 96, 192-199, doi:10.1210/jc.2010-0989. 
31. Keuper, M.; Jastroch, M. The Good and the BAT of Metabolic Sex Differences in Thermogenic Human Adipose Tissue. Molecular and Cellular Endocrinology 2021, 533, 111337, doi:10.1016/..mce.2021.111337.

32. Rudnicki, M.; Abdifarkosh, G.; Rezvan, O.; Nwadozi, E.; Roudier, E.; Haas, T.L. Female Mice Have Higher Angiogenesis in Perigonadal Adipose Tissue Than Males in Response to High-Fat Diet. Front. Physiol. 2018, 9, 1452, doi:10.3389/fphys.2018.01452.

33. Rodríguez-Cuenca, S.; Monjo, M.; Gianotti, M.; Proenza, A.M.; Roca, P. Expression of Mitochondrial Biogenesis-Signaling Factors in Brown Adipocytes Is Influenced Specifically by $17 \beta$-Estradiol, Testosterone, and Progesterone. American Journal of Physiology-Endocrinology and Metabolism 2007, 292, E340-E346, doi:10.1152/ajpendo.00175.2006.

34. Löfgren, P.; Hoffstedt, J.; Rydén, M.; Thörne, A.; Holm, C.; Wahrenberg, H.; Arner, P. Major Gender Differences in the Lipolytic Capacity of Abdominal Subcutaneous Fat Cells in Obesity Observed before and after Long-Term Weight Reduction. The Journal of Clinical Endocrinology \& Metabolism 2002, 87, 764-771, doi:10.1210/jcem.87.2.8254.

35. Riis-Vestergaard, M.J.; Richelsen, B.; Bruun, J.M.; Li, W.; Hansen, J.B.; Pedersen, S.B. Beta-1 and Not Beta-3 Adrenergic Receptors May Be the Primary Regulator of Human Brown Adipocyte Metabolism. The Journal of Clinical Endocrinology \& Metabolism 2020, 105, e994-e1005, doi:10.1210/clinem/dgz298.

36. Kaikaew, K.; van den Beukel, J.C.; Neggers, S.J.C.M.M.; Themmen, A.P.N.; Visser, J.A.; Grefhorst, A. Sex Difference in Cold Perception and Shivering Onset upon Gradual Cold Exposure. Journal of Thermal Biology 2018, 77, 137-144, doi:10.1016/j.jtherbio.2018.08.016.

37. Choi, D.K.; Oh, T.S.; Choi, J.-W.; Mukherjee, R.; Wang, X.; Liu, H.; Yun, J.W. Gender Difference in Proteome of Brown Adipose Tissues between Male and Female Rats Exposed to a High Fat Diet. Cell Physiol Biochem 2011, 28, 933-948, doi:10.1159/000335807.

38. Nookaew, I.; Svensson, P.-A.; Jacobson, P.; Jernås, M.; Taube, M.; Larsson, I.; AnderssonAssarsson, J.C.; Sjöström, L.; Froguel, P.; Walley, A.; et al. Adipose Tissue Resting Energy Expenditure and Expression of Genes Involved in Mitochondrial Function Are Higher in Women than in Men. The Journal of Clinical Endocrinology \& Metabolism 2013, 98, E370-E378, doi:10.1210/jc.2012-2764.

39. van den Beukel, J.C.; Grefhorst, A.; Hoogduijn, M.J.; Steenbergen, J.; Mastroberardino, P.G.; Dor, F.J.M.F.; Themmen, A.P.N. Women Have More Potential to Induce Browning of Perirenal Adipose Tissue than Men: Browning of Perirenal Fat in Women. Obesity 2015, 23, 1671-1679, doi:10.1002/oby.21166.

40. Norheim, F.; Hasin-Brumshtein, Y.; Vergnes, L.; Chella Krishnan, K.; Pan, C.; Seldin, M.M.; Hui, S.T.; Mehrabian, M.; Zhou, Z.; Gupta, S.; et al. Gene-by-Sex Interactions in Mitochondrial Functions and Cardio-Metabolic Traits. Cell Metabolism 2019, 29, 932-949.e4, doi:10.1016/j.cmet.2018.12.013.

41. Persichetti, A.; Sciuto, R.; Rea, S.; Basciani, S.; Lubrano, C.; Mariani, S.; Ulisse, S.; Nofroni, I.; Maini, C.L.; Gnessi, L. Prevalence, Mass, and Glucose-Uptake Activity of 18F-FDG-Detected Brown Adipose Tissue in Humans Living in a Temperate Zone of Italy. PLoS ONE 2013, 8, e63391, doi:10.1371/journal.pone.0063391.

42. Lecoultre, $V$. ; Ravussin, E. Brown Adipose Tissue and Aging: Current Opinion in Clinical Nutrition and Metabolic Care 2011, 14, 1-6, doi:10.1097/MCO.0b013e328341221e.

43. Lenaz, G. Role of Mitochondria in Oxidative Stress and Ageing. Biochimica et Biophysica Acta (BBA) - Bioenergetics 1998, 1366, 53-67, doi:10.1016/S0005-2728(98)00120-0.

44. Bratic, A.; Larsson, N.-G. The Role of Mitochondria in Aging. J. Clin. Invest. 2013, 123, 951-957, doi:10.1172/JCl64125.

45. Wu, J.; Boström, P.; Sparks, L.M.; Ye, L.; Choi, J.H.; Giang, A.-H.; Khandekar, M.; Virtanen, K.A.; Nuutila, P.; Schaart, G.; et al. Beige Adipocytes Are a Distinct Type of Thermogenic Fat Cell in Mouse and Human. Cell 2012, 150, 366-376, doi:10.1016/j.cell.2012.05.016. 
46. Khanh, V.C.; Zulkifli, A.F.; Tokunaga, C.; Yamashita, T.; Hiramatsu, Y.; Ohneda, O. Aging Impairs Beige Adipocyte Differentiation of Mesenchymal Stem Cells via the Reduced Expression of Sirtuin 1. Biochemical and Biophysical Research Communications 2018, 500, 682-690, doi:10.1016/j.bbrc.2018.04.136.

47. Nedergaard, J.; Bengtsson, T.; Cannon, B. Unexpected Evidence for Active Brown Adipose Tissue in Adult Humans. American Journal of Physiology-Endocrinology and Metabolism 2007, 293, E444-E452, doi:10.1152/ajpendo.00691.2006.

48. Bahler, L.; Verberne, H.J.; Admiraal, W.M.; Stok, W.J.; Soeters, M.R.; Hoekstra, J.B.; Holleman, F. Differences in Sympathetic Nervous Stimulation of Brown Adipose Tissue Between the Young and Old, and the Lean and Obese. $J$ Nucl Med 2016, 57, 372-377, doi:10.2967/jnumed.115.165829.

49. Matsushita, M.; Yoneshiro, T.; Aita, S.; Kameya, T.; Sugie, H.; Saito, M. Impact of Brown Adipose Tissue on Body Fatness and Glucose Metabolism in Healthy Humans. Int J Obes 2014, 38, 812817, doi:10.1038/ijo.2013.206.

50. Soumano, K. Glucocorticoids Inhibit the Transcriptional Response of the Uncoupling Protein-1 Gene to Adrenergic Stimulation in a Brown Adipose Cell Line. Molecular and Cellular Endocrinology 2000, 165, 7-15, doi:10.1016/S0303-7207(00)00276-8.

51. Lee, J.-Y.; Takahashi, N.; Yasubuchi, M.; Kim, Y.-I.; Hashizaki, H.; Kim, M.-J.; Sakamoto, T.; Goto, T.; Kawada, T. Triiodothyronine Induces UCP-1 Expression and Mitochondrial Biogenesis in Human Adipocytes. American Journal of Physiology-Cell Physiology 2012, 302, C463-C472, doi:10.1152/ajpcell.00010.2011.

52. Martínez-Sánchez, N.; Moreno-Navarrete, J.M.; Contreras, C.; Rial-Pensado, E.; Fernø, J.; Nogueiras, R.; Diéguez, C.; Fernández-Real, J.-M.; López, M. Thyroid Hormones Induce Browning of White Fat. Journal of Endocrinology 2017, 232, 351-362, doi:10.1530/JOE-16-0425.

53. Schulz, T.J.; Huang, T.L.; Tran, T.T.; Zhang, H.; Townsend, K.L.; Shadrach, J.L.; Cerletti, M.; McDougall, L.E.; Giorgadze, N.; Tchkonia, T.; et al. Identification of Inducible Brown Adipocyte Progenitors Residing in Skeletal Muscle and White Fat. Proc Natl Acad Sci USA 2011, 108, 143148, doi:10.1073/pnas.1010929108.

54. Lee, Y.-H.; Petkova, A.P.; Mottillo, E.P.; Granneman, J.G. In Vivo Identification of Bipotential Adipocyte Progenitors Recruited by B3-Adrenoceptor Activation and High-Fat Feeding. Cell Metabolism 2012, 15, 480-491, doi:10.1016/j.cmet.2012.03.009.

55. Berry, R.; Rodeheffer, M.S. Characterization of the Adipocyte Cellular Lineage in Vivo. Nat Cell Biol 2013, 15, 302-308, doi:10.1038/ncb2696.

56. Holzman, M.A.; Ryckman, A.; Finkelstein, T.M.; Landry-Truchon, K.; Schindler, K.A.; Bergmann, J.M.; Jeannotte, L.; Mansfield, J.H. HOXA5 Participates in Brown Adipose Tissue and Epaxial Skeletal Muscle Patterning and in Brown Adipocyte Differentiation. Front. Cell Dev. Biol. 2021, 9, 632303, doi:10.3389/fcell.2021.632303.

57. An, Y.; Wang, G.; Diao, Y.; Long, Y.; Fu, X.; Weng, M.; Zhou, L.; Sun, K.; Cheung, T.H.; Ip, N.Y.; et al. A Molecular Switch Regulating Cell Fate Choice between Muscle Progenitor Cells and Brown Adipocytes. Developmental Cell 2017, 41, 382-391.e5, doi:10.1016/j.devcel.2017.04.012.

58. Timmons, J.A.; Wennmalm, K.; Larsson, O.; Walden, T.B.; Lassmann, T.; Petrovic, N.; Hamilton, D.L.; Gimeno, R.E.; Wahlestedt, C.; Baar, K.; et al. Myogenic Gene Expression Signature Establishes That Brown and White Adipocytes Originate from Distinct Cell Lineages. Proceedings of the National Academy of Sciences 2007, 104, 4401-4406, doi:10.1073/pnas.0610615104.

59. Forner, F.; Kumar, C.; Luber, C.A.; Fromme, T.; Klingenspor, M.; Mann, M. Proteome Differences between Brown and White Fat Mitochondria Reveal Specialized Metabolic Functions. Cell Metabolism 2009, 10, 324-335, doi:10.1016/i.cmet.2009.08.014.

60. Sharp, L.Z.; Shinoda, K.; Ohno, H.; Scheel, D.W.; Tomoda, E.; Ruiz, L.; Hu, H.; Wang, L.; Pavlova, Z.; Gilsanz, V.; et al. Human BAT Possesses Molecular Signatures That Resemble Beige/Brite Cells. PLoS ONE 2012, 7, e49452, doi:10.1371/journal.pone.0049452. 
61. Xue, R.; Lynes, M.D.; Dreyfuss, J.M.; Shamsi, F.; Schulz, T.J.; Zhang, H.; Huang, T.L.; Townsend, K.L.; Li, Y.; Takahashi, H.; et al. Clonal Analyses and Gene Profiling Identify Genetic Biomarkers of the Thermogenic Potential of Human Brown and White Preadipocytes. Nat Med 2015, 21, 760768, doi:10.1038/nm.3881.

62. Seale, P.; Bjork, B.; Yang, W.; Kajimura, S.; Chin, S.; Kuang, S.; Scimè, A.; Devarakonda, S.; Conroe, H.M.; Erdjument-Bromage, H.; et al. PRDM16 Controls a Brown Fat/Skeletal Muscle Switch. Nature 2008, 454, 961-967, doi:10.1038/nature07182.

63. Lidell, M.E.; Betz, M.J.; Leinhard, O.D.; Heglind, M.; Elander, L.; Slawik, M.; Mussack, T.; Nilsson, D.; Romu, T.; Nuutila, P.; et al. Evidence for Two Types of Brown Adipose Tissue in Humans. Nat Med 2013, 19, 631-634, doi:10.1038/nm.3017.

64. Sun, L.; Xie, H.; Mori, M.A.; Alexander, R.; Yuan, B.; Hattangadi, S.M.; Liu, Q.; Kahn, C.R.; Lodish, H.F. Mir193b-365 Is Essential for Brown Fat Differentiation. Nat Cell Biol 2011, 13, 958-965, doi:10.1038/ncb2286.

65. Güller, I.; McNaughton, S.; Crowley, T.; Gilsanz, V.; Kajimura, S.; Watt, M.; Russell, A.P. Comparative Analysis of MicroRNA Expression in Mouse and Human Brown Adipose Tissue. BMC Genomics 2015, 16, 820, doi:10.1186/s12864-015-2045-8.

66. Kim, H.-J.; Cho, H.; Alexander, R.; Patterson, H.C.; Gu, M.; Lo, K.A.; Xu, D.; Goh, V.J.; Nguyen, L.N.; Chai, X.; et al. MicroRNAs Are Required for the Feature Maintenance and Differentiation of Brown Adipocytes. Diabetes 2014, 63, 4045-4056, doi:10.2337/db14-0466.

67. Mori, M.; Nakagami, H.; Rodriguez-Araujo, G.; Nimura, K.; Kaneda, Y. Essential Role for MiR196a in Brown Adipogenesis of White Fat Progenitor Cells. PLoS Biol 2012, 10, e1001314, doi:10.1371/journal.pbio.1001314.

68. Liu, W.; Bi, P.; Shan, T.; Yang, X.; Yin, H.; Wang, Y.-X.; Liu, N.; Rudnicki, M.A.; Kuang, S. MiR133a Regulates Adipocyte Browning In Vivo. PLoS Genet 2013, 9, e1003626, doi:10.1371/journal.pgen.1003626.

69. Svensson, P.-A.; Lindberg, K.; Hoffmann, J.M.; Taube, M.; Pereira, M.J.; Mohsen-Kanson, T.; Hafner, A.-L.; Rizell, M.; Palming, J.; Dani, C.; et al. Characterization of Brown Adipose Tissue in the Human Perirenal Depot: BAT in the Human Perirenal Depot. Obesity 2014, 22, 1830-1837, doi:10.1002/oby.20765.

70. Cypess, A.M.; White, A.P.; Vernochet, C.; Schulz, T.J.; Xue, R.; Sass, C.A.; Huang, T.L.; RobertsToler, C.; Weiner, L.S.; Sze, C.; et al. Anatomical Localization, Gene Expression Profiling and Functional Characterization of Adult Human Neck Brown Fat. Nat Med 2013, 19, 635-639, doi:10.1038/nm.3112.

71. Zuriaga, M.A.; Fuster, J.J.; Gokce, N.; Walsh, K. Humans and Mice Display Opposing Patterns of "Browning" Gene Expression in Visceral and Subcutaneous White Adipose Tissue Depots. Front. Cardiovasc. Med. 2017, 4, 27, doi:10.3389/fcvm.2017.00027.

72. Young, P.; Arch, J.R.S.; Ashwell, M. Brown Adipose Tissue in the Parametrial Fat Pad of the Mouse. FEBS Letters 1984, 167, 10-14, doi:10.1016/0014-5793(84)80822-4.

73. Haman, F.; Mantha, O.L.; Cheung, S.S.; DuCharme, M.B.; Taber, M.; Blondin, D.P.; McGarr, G.W.; Hartley, G.L.; Hynes, Z.; Basset, F.A. Oxidative Fuel Selection and Shivering Thermogenesis during a 12- and 24-h Cold-Survival Simulation. Journal of Applied Physiology 2016, 120, 640-648, doi:10.1152/japplphysiol.00540.2015.

74. Bal, N.C.; Maurya, S.K.; Pani, S.; Sethy, C.; Banerjee, A.; Das, S.; Patnaik, S.; Kundu, C.N. Mild Cold Induced Thermogenesis: Are BAT and Skeletal Muscle Synergistic Partners? Bioscience Reports 2017, 37, BSR20171087, doi:10.1042/BSR20171087.

75. Kern, P.A.; Finlin, B.S.; Zhu, B.; Rasouli, N.; McGehee, R.E.; Westgate, P.M.; DupontVersteegden, E.E. The Effects of Temperature and Seasons on Subcutaneous White Adipose Tissue in Humans: Evidence for Thermogenic Gene Induction. The Journal of Clinical Endocrinology \& Metabolism 2014, 99, E2772-E2779, doi:10.1210/jc.2014-2440.

76. Betz, M.J.; Slawik, M.; Lidell, M.E.; Osswald, A.; Heglind, M.; Nilsson, D.; Lichtenauer, U.D.; Mauracher, B.; Mussack, T.; Beuschlein, F.; et al. Presence of Brown Adipocytes in 
Retroperitoneal Fat From Patients With Benign Adrenal Tumors: Relationship With Outdoor Temperature. The Journal of Clinical Endocrinology \& Metabolism 2013, 98, 4097-4104, doi:10.1210/jc.2012-3535.

77. van der Lans, A.A.J.J.; Hoeks, J.; Brans, B.; Vijgen, G.H.E.J.; Visser, M.G.W.; Vosselman, M.J.; Hansen, J.; Jörgensen, J.A.; Wu, J.; Mottaghy, F.M.; et al. Cold Acclimation Recruits Human Brown Fat and Increases Nonshivering Thermogenesis. J. Clin. Invest. 2013, 123, 3395-3403, doi:10.1172/JCl68993.

78. Weir, G.; Ramage, L.E.; Akyol, M.; Rhodes, J.K.; Kyle, C.J.; Fletcher, A.M.; Craven, T.H.; Wakelin, S.J.; Drake, A.J.; Gregoriades, M.-L.; et al. Substantial Metabolic Activity of Human Brown Adipose Tissue during Warm Conditions and Cold-Induced Lipolysis of Local Triglycerides. Cell Metabolism 2018, 27, 1348-1355.e4, doi:10.1016/j.cmet.2018.04.020.

79. Ouellet, V.; Labbé, S.M.; Blondin, D.P.; Phoenix, S.; Guérin, B.; Haman, F.; Turcotte, E.E.; Richard, D.; Carpentier, A.C. Brown Adipose Tissue Oxidative Metabolism Contributes to Energy Expenditure during Acute Cold Exposure in Humans. J. Clin. Invest. 2012, 122, 545-552, doi:10.1172/JCl60433.

80. Blondin, D.P.; Labbé, S.M.; Noll, C.; Kunach, M.; Phoenix, S.; Guérin, B.; Turcotte, É.E.; Haman, F.; Richard, D.; Carpentier, A.C. Selective Impairment of Glucose but Not Fatty Acid or Oxidative Metabolism in Brown Adipose Tissue of Subjects With Type 2 Diabetes. Diabetes 2015, 64, 23882397, doi:10.2337/db14-1651.

81. Blondin, D.P.; Carpentier, A.C. The Role of BAT in Cardiometabolic Disorders and Aging. Best Practice \& Research Clinical Endocrinology \& Metabolism 2016, 30, 497-513, doi:10.1016/j.beem.2016.09.002.

82. Suchacki, K.J.; Stimson, R.H. Nutritional Regulation of Human Brown Adipose Tissue. Nutrients 2021, 13, 1748, doi:10.3390/nu13061748.

83. Orava, J.; Nuutila, P.; Lidell, M.E.; Oikonen, V.; Noponen, T.; Viljanen, T.; Scheinin, M.; Taittonen, M.; Niemi, T.; Enerbäck, S.; et al. Different Metabolic Responses of Human Brown Adipose Tissue to Activation by Cold and Insulin. Cell Metabolism 2011, 14, 272-279, doi:10.1016/j.cmet.2011.06.012.

84. Chondronikola, M.; Volpi, E.; Børsheim, E.; Porter, C.; Annamalai, P.; Enerbäck, S.; Lidell, M.E.; Saraf, M.K.; Labbe, S.M.; Hurren, N.M.; et al. Brown Adipose Tissue Improves Whole-Body Glucose Homeostasis and Insulin Sensitivity in Humans. Diabetes 2014, 63, 4089-4099, doi: $10.2337 / \mathrm{db} 14-0746$.

85. Yoneshiro, T.; Aita, S.; Matsushita, M.; Okamatsu-Ogura, Y.; Kameya, T.; Kawai, Y.; Miyagawa, M.; Tsujisaki, M.; Saito, M. Age-Related Decrease in Cold-Activated Brown Adipose Tissue and Accumulation of Body Fat in Healthy Humans. Obesity 2011, 19, 1755-1760, doi:10.1038/oby.2011.125.

86. Himms-Hagen, J.; Cui, J.; Danforth, E.; Taatjes, D.J.; Lang, S.S.; Waters, B.L.; Claus, T.H. Effect of CL-316,243, a Thermogenic Beta 3-Agonist, on Energy Balance and Brown and White Adipose Tissues in Rats. American Journal of Physiology-Regulatory, Integrative and Comparative Physiology 1994, 266, R1371-R1382, doi:10.1152/ajpregu.1994.266.4.R1371.

87. Granneman, J.G.; Li, P.; Zhu, Z.; Lu, Y. Metabolic and Cellular Plasticity in White Adipose Tissue I: Effects of $\beta_{3}$-Adrenergic Receptor Activation. American Journal of Physiology-Endocrinology and Metabolism 2005, 289, E608-E616, doi:10.1152/ajpendo.00009.2005.

88. Larsen, T.M.; Toubro, S.; van Baak, M.A.; Gottesdiener, K.M.; Larson, P.; Saris, W.H.; Astrup, A. Effect of a 28-d Treatment with L-796568, a Novel B3-Adrenergic Receptor Agonist, on Energy Expenditure and Body Composition in Obese Men. The American Journal of Clinical Nutrition 2002, 76, 780-788, doi:10.1093/ajcn/76.4.780.

89. Weyer, C.; Tataranni, P.A.; Snitker, S.; Danforth, E.; Ravussin, E. Increase in Insulin Action and Fat Oxidation after Treatment with CL 316,243, a Highly Selective Beta3-Adrenoceptor Agonist in Humans. Diabetes 1998, 47, 1555-1561, doi:10.2337/diabetes.47.10.1555. 
90. Cypess, A.M.; Weiner, L.S.; Roberts-Toler, C.; Elía, E.F.; Kessler, S.H.; Kahn, P.A.; English, J.; Chatman, K.; Trauger, S.A.; Doria, A.; et al. Activation of Human Brown Adipose Tissue by a B3Adrenergic Receptor Agonist. Cell Metabolism 2015, 21, 33-38, doi:10.1016/j.cmet.2014.12.009.

91. Blondin, D.P.; Nielsen, S.; Kuipers, E.N.; Severinsen, M.C.; Jensen, V.H.; Miard, S.; Jespersen, N.Z.; Kooijman, S.; Boon, M.R.; Fortin, M.; et al. Human Brown Adipocyte Thermogenesis Is Driven by B2-AR Stimulation. Cell Metabolism 2020, 32, 287-300.e7, doi:10.1016/j.cmet.2020.07.005.

92. Carey, A.L.; Formosa, M.F.; Van Every, B.; Bertovic, D.; Eikelis, N.; Lambert, G.W.; Kalff, V.; Duffy, S.J.; Cherk, M.H.; Kingwell, B.A. Ephedrine Activates Brown Adipose Tissue in Lean but Not Obese Humans. Diabetologia 2013, 56, 147-155, doi:10.1007/s00125-012-2748-1

93. O'Mara, A.E.; Johnson, J.W.; Linderman, J.D.; Brychta, R.J.; McGehee, S.; Fletcher, L.A.; Fink, Y.A.; Kapuria, D.; Cassimatis, T.M.; Kelsey, N.; et al. Chronic Mirabegron Treatment Increases Human Brown Fat, HDL Cholesterol, and Insulin Sensitivity. Journal of Clinical Investigation 2020, 130, 2209-2219, doi:10.1172/JCl131126.

94. Warner, A.; Mittag, J. Breaking BAT: Can Browning Create a Better White? Journal of Endocrinology 2016, 228, R19-R29, doi:10.1530/JOE-15-0408.

95. Kaisanlahti, A.; Glumoff, T. Browning of White Fat: Agents and Implications for Beige Adipose Tissue to Type 2 Diabetes. J Physiol Biochem 2019, 75, 1-10, doi:10.1007/s13105-018-0658-5.

96. Markan, K.R.; Naber, M.C.; Ameka, M.K.; Anderegg, M.D.; Mangelsdorf, D.J.; Kliewer, S.A.; Mohammadi, M.; Potthoff, M.J. Circulating FGF21 Is Liver Derived and Enhances Glucose Uptake During Refeeding and Overfeeding. Diabetes 2014, 63, 4057-4063, doi:10.2337/db14-0595.

97. Hondares, E.; Gallego-Escuredo, J.M.; Flachs, P.; Frontini, A.; Cereijo, R.; Goday, A.; Perugini, J.; Kopecky, P.; Giralt, M.; Cinti, S.; et al. Fibroblast Growth Factor-21 Is Expressed in Neonatal and Pheochromocytoma-Induced Adult Human Brown Adipose Tissue. Metabolism 2014, 63, 312-317, doi:10.1016/j.metabol.2013.11.014.

98. Fisher, f. M.; Kleiner, S.; Douris, N.; Fox, E.C.; Mepani, R.J.; Verdeguer, F.; Wu, J.; Kharitonenkov, A.; Flier, J.S.; Maratos-Flier, E.; et al. FGF21 Regulates PGC-1 and Browning of White Adipose Tissues in Adaptive Thermogenesis. Genes \& Development 2012, 26, 271-281, doi:10.1101/gad.177857.111.

99. Schlein, C.; Talukdar, S.; Heine, M.; Fischer, A.W.; Krott, L.M.; Nilsson, S.K.; Brenner, M.B.; Heeren, J.; Scheja, L. FGF21 Lowers Plasma Triglycerides by Accelerating Lipoprotein Catabolism in White and Brown Adipose Tissues. Cell Metabolism 2016, 23, 441-453, doi:10.1016/j.cmet.2016.01.006.

100. Talukdar, S.; Zhou, Y.; Li, D.; Rossulek, M.; Dong, J.; Somayaji, V.; Weng, Y.; Clark, R.; Lanba, A.; Owen, B.M.; et al. A Long-Acting FGF21 Molecule, PF-05231023, Decreases Body Weight and Improves Lipid Profile in Non-Human Primates and Type 2 Diabetic Subjects. Cell Metabolism 2016, 23, 427-440, doi:10.1016/i.cmet.2016.02.001.

101. Gaich, G.; Chien, J.Y.; Fu, H.; Glass, L.C.; Deeg, M.A.; Holland, W.L.; Kharitonenkov, A.; Bumol, T.; Schilske, H.K.; Moller, D.E. The Effects of LY2405319, an FGF21 Analog, in Obese Human Subjects with Type 2 Diabetes. Cell Metabolism 2013, 18, 333-340, doi:10.1016/i.cmet.2013.08.005.

102. Xia, Y.; Kelton, C.M.L.; Guo, J.J.; Bian, B.; Heaton, P.C. Treatment of Obesity: Pharmacotherapy Trends in the United States from 1999 to 2010: Pharmacotherapy Treatment of Obesity. Obesity 2015, 23, 1721-1728, doi:10.1002/oby.21136.

103. Roberts, L.D.; Boström, P.; O’Sullivan, J.F.; Schinzel, R.T.; Lewis, G.D.; Dejam, A.; Lee, Y.-K.; Palma, M.J.; Calhoun, S.; Georgiadi, A.; et al. $\beta$-Aminoisobutyric Acid Induces Browning of White Fat and Hepatic $\beta$-Oxidation and Is Inversely Correlated with Cardiometabolic Risk Factors. Cell Metabolism 2014, 19, 96-108, doi:10.1016/j.cmet.2013.12.003.

104. Vegiopoulos, A.; Muller-Decker, K.; Strzoda, D.; Schmitt, I.; Chichelnitskiy, E.; Ostertag, A.; Diaz, M.B.; Rozman, J.; Hrabe de Angelis, M.; Nusing, R.M.; et al. Cyclooxygenase-2 Controls Energy 
Homeostasis in Mice by de Novo Recruitment of Brown Adipocytes. Science 2010, 328, 11581161, doi:10.1126/science.1186034.

105. Qian, S.-W.; Tang, Y.; Li, X.; Liu, Y.; Zhang, Y.-Y.; Huang, H.-Y.; Xue, R.-D.; Yu, H.-Y.; Guo, L.; Gao, H.-D.; et al. BMP4-Mediated Brown Fat-like Changes in White Adipose Tissue Alter Glucose and Energy Homeostasis. Proc Natl Acad Sci USA 2013, 110, E798-E807, doi:10.1073/pnas.1215236110.

106. Gustafson, B.; Hammarstedt, A.; Hedjazifar, S.; Hoffmann, J.M.; Svensson, P.-A.; Grimsby, J.; Rondinone, C.; Smith, U. BMP4 and BMP Antagonists Regulate Human White and Beige Adipogenesis. Diabetes 2015, 64, 1670-1681, doi:10.2337/db14-1127.

107. Elsen, M.; Raschke, S.; Tennagels, N.; Schwahn, U.; Jelenik, T.; Roden, M.; Romacho, T.; Eckel, J. BMP4 and BMP7 Induce the White-to-Brown Transition of Primary Human Adipose Stem Cells. American Journal of Physiology-Cell Physiology 2014, 306, C431-C440, doi:10.1152/ajpcell.00290.2013.

108. Braga, M.; Reddy, S.T.; Vergnes, L.; Pervin, S.; Grijalva, V.; Stout, D.; David, J.; Li, X.; Tomasian, V.; Reid, C.B.; et al. Follistatin Promotes Adipocyte Differentiation, Browning, and Energy Metabolism. Journal of Lipid Research 2014, 55, 375-384, doi:10.1194/j|r.M039719.

109. Singh, R.; Braga, M.; Reddy, S.T.; Lee, S.-J.; Parveen, M.; Grijalva, V.; Vergnes, L.; Pervin, S. Follistatin Targets Distinct Pathways To Promote Brown Adipocyte Characteristics in Brown and White Adipose Tissues. Endocrinology 2017, 158, 1217-1230, doi:10.1210/en.2016-1607.

110. Braga, M.; Pervin, S.; Norris, K.; Bhasin, S.; Singh, R. Inhibition of in Vitro and in Vivo Brown Fat Differentiation Program by Myostatin: Brown Fat and Myostatin. Obesity 2013, 21, 1180-1188, doi:10.1002/oby.20117.

111. Choi, S.-S.; Kim, E.-S.; Jung, J.-E.; Marciano, D.P.; Jo, A.; Koo, J.Y.; Choi, S.Y.; Yang, Y.R.; Jang, H.-J.; Kim, E.-K.; et al. PPARy Antagonist Gleevec Improves Insulin Sensitivity and Promotes the Browning of White Adipose Tissue. Diabetes 2016, 65, 829-839, doi:10.2337/db151382.

112. Ohno, H.; Shinoda, K.; Spiegelman, B.M.; Kajimura, S. PPARy Agonists Induce a White-to-Brown Fat Conversion through Stabilization of PRDM16 Protein. Cell Metabolism 2012, 15, 395-404, doi:10.1016/i.cmet.2012.01.019.

113. Loh, R.K.C.; Formosa, M.F.; Eikelis, N.; Bertovic, D.A.; Anderson, M.J.; Barwood, S.A.; Nanayakkara, S.; Cohen, N.D.; La Gerche, A.; Reutens, A.T.; et al. Pioglitazone Reduces ColdInduced Brown Fat Glucose Uptake despite Induction of Browning in Cultured Human Adipocytes: A Randomised, Controlled Trial in Humans. Diabetologia 2018, 61, 220-230, doi:10.1007/s00125-017-4479-9.

114. Pi-Sunyer, X.; Astrup, A.; Fujioka, K.; Greenway, F.; Halpern, A.; Krempf, M.; Lau, D.C.W.; le Roux, C.W.; Violante Ortiz, R.; Jensen, C.B.; et al. A Randomized, Controlled Trial of $3.0 \mathrm{Mg}$ of Liraglutide in Weight Management. $N$ Engl $J$ Med 2015, 373, 11-22, doi:10.1056/NEJMoa1411892.

115. Beiroa, D.; Imbernon, M.; Gallego, R.; Senra, A.; Herranz, D.; Villarroya, F.; Serrano, M.; Ferno, J.; Salvador, J.; Escalada, J.; et al. GLP-1 Agonism Stimulates Brown Adipose Tissue Thermogenesis and Browning Through Hypothalamic AMPK. Diabetes 2014, 63, 3346-3358, doi:10.2337/db14-0302.

116. Teodoro, J.S.; Zouhar, P.; Flachs, P.; Bardova, K.; Janovska, P.; Gomes, A.P.; Duarte, F.V.; Varela, A.T.; Rolo, A.P.; Palmeira, C.M.; et al. Enhancement of Brown Fat Thermogenesis Using Chenodeoxycholic Acid in Mice. Int J Obes 2014, 38, 1027-1034, doi:10.1038/ijo.2013.230.

117. Broeders, E.P.M.; Nascimento, E.B.M.; Havekes, B.; Brans, B.; Roumans, K.H.M.; Tailleux, A.; Schaart, G.; Kouach, M.; Charton, J.; Deprez, B.; et al. The Bile Acid Chenodeoxycholic Acid Increases Human Brown Adipose Tissue Activity. Cell Metabolism 2015, 22, 418-426, doi:10.1016/j.cmet.2015.07.002. 
118. Song, N.-J.; Choi, S.; Rajbhandari, P.; Chang, S.-H.; Kim, S.; Vergnes, L.; Kwon, S.-M.; Yoon, J.H.; Lee, S.; Ku, J.-M.; et al. Prdm4 Induction by the Small Molecule Butein Promotes White Adipose Tissue Browning. Nat Chem Biol 2016, 12, 479-481, doi:10.1038/nchembio.2081.

119. Baskaran, P.; Krishnan, V.; Ren, J.; Thyagarajan, B. Capsaicin Induces Browning of White Adipose Tissue and Counters Obesity by Activating TRPV1 Channel-Dependent Mechanisms: TRPV1 Activates Browning of WAT to Counter Obesity. British Journal of Pharmacology 2016, 173, 2369-2389, doi:10.1111/bph.13514.

120. Yoneshiro, T.; Aita, S.; Matsushita, M.; Kayahara, T.; Kameya, T.; Kawai, Y.; Iwanaga, T.; Saito, M. Recruited Brown Adipose Tissue as an Antiobesity Agent in Humans. J. Clin. Invest. 2013, 123, 3404-3408, doi:10.1172/JCl67803.

121. Carriere, A.; Jeanson, Y.; Berger-Muller, S.; Andre, M.; Chenouard, V.; Arnaud, E.; Barreau, C.; Walther, R.; Galinier, A.; Wdziekonski, B.; et al. Browning of White Adipose Cells by Intermediate Metabolites: An Adaptive Mechanism to Alleviate Redox Pressure. Diabetes 2014, 63, 32533265, doi:10.2337/db13-1885.

122. Stanford, K.I.; Middelbeek, R.J.W.; Goodyear, L.J. Exercise Effects on White Adipose Tissue: Beiging and Metabolic Adaptations. Diabetes 2015, 64, 2361-2368, doi:10.2337/db15-0227.

123. Trevellin, E.; Scorzeto, M.; Olivieri, M.; Granzotto, M.; Valerio, A.; Tedesco, L.; Fabris, R.; Serra, R.; Quarta, M.; Reggiani, C.; et al. Exercise Training Induces Mitochondrial Biogenesis and Glucose Uptake in Subcutaneous Adipose Tissue Through ENOS-Dependent Mechanisms. Diabetes 2014, 63, 2800-2811, doi:10.2337/db13-1234.

124. Boström, P.; Wu, J.; Jedrychowski, M.P.; Korde, A.; Ye, L.; Lo, J.C.; Rasbach, K.A.; Boström, E.A.; Choi, J.H.; Long, J.Z.; et al. A PGC1-a-Dependent Myokine That Drives Brown-Fat-like Development of White Fat and Thermogenesis. Nature 2012, 481, 463-468, doi:10.1038/nature10777.

125. Lee, P.; Linderman, J.D.; Smith, S.; Brychta, R.J.; Wang, J.; Idelson, C.; Perron, R.M.; Werner, C.D.; Phan, G.Q.; Kammula, U.S.; et al. Irisin and FGF21 Are Cold-Induced Endocrine Activators of Brown Fat Function in Humans. Cell Metabolism 2014, 19, 302-309, doi:10.1016/j.cmet.2013.12.017.

126. Otero-Díaz, B.; Rodríguez-Flores, M.; Sánchez-Muñoz, V.; Monraz-Preciado, F.; OrdoñezOrtega, S.; Becerril-Elias, V.; Baay-Guzmán, G.; Obando-Monge, R.; García-García, E.; PalaciosGonzález, B.; et al. Exercise Induces White Adipose Tissue Browning Across the Weight Spectrum in Humans. Front Physiol 2018, 9, 1781, doi:10.3389/fphys.2018.01781.

127. Hecksteden, A.; Wegmann, M.; Steffen, A.; Kraushaar, J.; Morsch, A.; Ruppenthal, S.; Kaestner, L.; Meyer, T. Irisin and Exercise Training in Humans - Results from a Randomized Controlled Training Trial. BMC Med 2013, 11, 235, doi:10.1186/1741-7015-11-235.

128. Pardo, M.; Crujeiras, A.B.; Amil, M.; Aguera, Z.; Jiménez-Murcia, S.; Baños, R.; Botella, C.; de la Torre, R.; Estivill, X.; Fagundo, A.B.; et al. Association of Irisin with Fat Mass, Resting Energy Expenditure, and Daily Activity in Conditions of Extreme Body Mass Index. International Journal of Endocrinology 2014, 2014, 1-9, doi:10.1155/2014/857270.

129. Viitasalo, A.; Ågren, J.; Venäläinen, T.; Pihlajamäki, J.; Jääskeläinen, J.; Korkmaz, A.; Atalay, M.; Lakka, T.A. Association of Plasma Fatty Acid Composition with Plasma Irisin Levels in Normal Weight and Overweight/Obese Children. Pediatric Obesity 2016, 11, 299-305, doi:10.1111/ijpo.12062.

130. Hansen, J.S.; Pedersen, B.K.; Xu, G.; Lehmann, R.; Weigert, C.; Plomgaard, P. Exercise-Induced Secretion of FGF21 and Follistatin Are Blocked by Pancreatic Clamp and Impaired in Type 2 Diabetes. The Journal of Clinical Endocrinology \& Metabolism 2016, 101, 2816-2825, doi:10.1210/jc.2016-1681.

131. Knudsen, J.G.; Murholm, M.; Carey, A.L.; Biensø, R.S.; Basse, A.L.; Allen, T.L.; Hidalgo, J.; Kingwell, B.A.; Febbraio, M.A.; Hansen, J.B.; et al. Role of IL-6 in Exercise Training- and ColdInduced UCP1 Expression in Subcutaneous White Adipose Tissue. PLoS ONE 2014, 9, e84910, doi: 10.1371/journal.pone.0084910. 
132. Rao, R.R.; Long, J.Z.; White, J.P.; Svensson, K.J.; Lou, J.; Lokurkar, I.; Jedrychowski, M.P.; Ruas, J.L.; Wrann, C.D.; Lo, J.C.; et al. Meteorin-like Is a Hormone That Regulates Immune-Adipose Interactions to Increase Beige Fat Thermogenesis. Cell 2014, 157, 1279-1291, doi:10.1016/j.cell.2014.03.065.

133. Roberts, L.D.; Boström, P.; O'Sullivan, J.F.; Schinzel, R.T.; Lewis, G.D.; Dejam, A.; Lee, Y.-K.; Palma, M.J.; Calhoun, S.; Georgiadi, A.; et al. $\beta$-Aminoisobutyric Acid Induces Browning of White Fat and Hepatic $\beta$-Oxidation and Is Inversely Correlated with Cardiometabolic Risk Factors. Cell Metabolism 2014, 19, 96-108, doi:10.1016/j.cmet.2013.12.003.

134. Cao, L.; Choi, E.Y.; Liu, X.; Martin, A.; Wang, C.; Xu, X.; During, M.J. White to Brown Fat Phenotypic Switch Induced by Genetic and Environmental Activation of a HypothalamicAdipocyte Axis. Cell Metabolism 2011, 14, 324-338, doi:10.1016/j.cmet.2011.06.020.

135. Vidal, P.; Stanford, K.I. Exercise-Induced Adaptations to Adipose Tissue Thermogenesis. Front. Endocrinol. 2020, 11, 270, doi:10.3389/fendo.2020.00270.

136. Dewal, R.S.; Stanford, K.I. Effects of Exercise on Brown and Beige Adipocytes. Biochimica et Biophysica Acta (BBA) - Molecular and Cell Biology of Lipids 2019, 1864, 71-78, doi:10.1016/j.bbalip.2018.04.013.

137. Gharanei, S.; Shabir, K.; Brown, J.E.; Weickert, M.O.; Barber, T.M.; Kyrou, I.; Randeva, H.S. Regulatory MicroRNAs in Brown, Brite and White Adipose Tissue. Cells 2020, 9, 2489, doi:10.3390/cells9112489.

138. Chen, Y.; Pan, R.; Pfeifer, A. Regulation of Brown and Beige Fat by MicroRNAs. Pharmacology \& Therapeutics 2017, 170, 1-7, doi:10.1016/j.pharmthera.2016.10.004.

139. Fitter, S.; Vandyke, K.; Gronthos, S.; Zannettino, A.C.W. Suppression of PDGF-Induced PI3 Kinase Activity by Imatinib Promotes Adipogenesis and Adiponectin Secretion. Journal of Molecular Endocrinology 2012, 48, 229-240, doi:10.1530/JME-12-0003.

140. Sun, L.; Xie, H.; Mori, M.A.; Alexander, R.; Yuan, B.; Hattangadi, S.M.; Liu, Q.; Kahn, C.R.; Lodish, H.F. Mir193b-365 Is Essential for Brown Fat Differentiation. Nat Cell Biol 2011, 13, 958-965, doi: $10.1038 / n c b 2286$.

141. Oliverio, M.; Schmidt, E.; Mauer, J.; Baitzel, C.; Hansmeier, N.; Khani, S.; Konieczka, S.; PradasJuni, M.; Brodesser, S.; Van, T.-M.; et al. Dicer1-MiR-328-Bace1 Signalling Controls Brown Adipose Tissue Differentiation and Function. Nat Cell Biol 2016, 18, 328-336, doi:10.1038/ncb3316.

142. Meakin, P.J.; Harper, A.J.; Hamilton, D.L.; Gallagher, J.; McNeilly, A.D.; Burgess, L.A.; Vaanholt, L.M.; Bannon, K.A.; Latcham, J.; Hussain, I.; et al. Reduction in BACE1 Decreases Body Weight, Protects against Diet-Induced Obesity and Enhances Insulin Sensitivity in Mice. Biochemical Journal 2012, 441, 285-296, doi:10.1042/BJ20110512.

143. Wu, Y.; Zuo, J.; Zhang, Y.; Xie, Y.; Hu, F.; Chen, L.; Liu, B.; Liu, F. Identification of MiR-106b-93 as a Negative Regulator of Brown Adipocyte Differentiation. Biochemical and Biophysical Research Communications 2013, 438, 575-580, doi:10.1016/j.bbrc.2013.08.016.

144. Karbiener, M.; Pisani, D.F.; Frontini, A.; Oberreiter, L.M.; Lang, E.; Vegiopoulos, A.; Mössenböck, K.; Bernhardt, G.A.; Mayr, T.; Hildner, F.; et al. MicroRNA-26 Family Is Required for Human Adipogenesis and Drives Characteristics of Brown Adipocytes: MicroRNA-26 Family in Human Adipogenesis. Stem Cells 2014, 32, 1578-1590, doi:10.1002/stem.1603.

145. Giroud, M.; Pisani, D.F.; Karbiener, M.; Barquissau, V.; Ghandour, R.A.; Tews, D.; FischerPosovszky, P.; Chambard, J.-C.; Knippschild, U.; Niemi, T.; et al. MiR-125b Affects Mitochondrial Biogenesis and Impairs Brite Adipocyte Formation and Function. Molecular Metabolism 2016, 5, 615-625, doi:10.1016/j.molmet.2016.06.005.

146. Hu, F.; Wang, M.; Xiao, T.; Yin, B.; He, L.; Meng, W.; Dong, M.; Liu, F. MiR-30 Promotes Thermogenesis and the Development of Beige Fat by Targeting RIP140. Diabetes 2015, 64, 2056-2068, doi:10.2337/db14-1117. 
147. Fritah, A.; Christian, M.; Parker, M.G. The Metabolic Coregulator RIP140: An Update. American Journal of Physiology-Endocrinology and Metabolism 2010, 299, E335-E340, doi:10.1152/ajpendo.00243.2010.

148. Zhang, H.; Guan, M.; Townsend, K.L.; Huang, T.L.; An, D.; Yan, X.; Xue, R.; Schulz, T.J.; Winnay, J.; Mori, M.; et al. MicroRNA-455 Regulates Brown Adipogenesis via a Novel HIF1an-AMPK PGC1a Signaling Network. EMBO Rep 2015, 16, 1378-1393, doi:10.15252/embr.201540837.

149. Pan, D.; Mao, C.; Quattrochi, B.; Friedline, R.H.; Zhu, L.J.; Jung, D.Y.; Kim, J.K.; Lewis, B.; Wang, Y.-X. MicroRNA-378 Controls Classical Brown Fat Expansion to Counteract Obesity. Nat Commun 2014, 5, 4725, doi:10.1038/ncomms5725.

150. Francis, S.H.; Blount, M.A.; Corbin, J.D. Mammalian Cyclic Nucleotide Phosphodiesterases: Molecular Mechanisms and Physiological Functions. Physiological Reviews 2011, 91, 651-690, doi:10.1152/physrev.00030.2010.

151. Trayhurn, P.; Douglas, J.B.; McGuckin, M.M. Brown Adipose Tissue Thermogenesis Is 'Suppressed' during Lactation in Mice. Nature 1982, 298, 59-60, doi:10.1038/298059a0.

152. Rothwell, N.J.; Stock, M.J. A Role for Brown Adipose Tissue in Diet-Induced Thermogenesis. Nature 1979, 281, 31-35, doi:10.1038/281031a0.

153. Osman, F.; Franklyn, J.A.; Daykin, J.; Chowdhary, S.; Holder, R.L.; Sheppard, M.C.; Gammage, M.D. Heart Rate Variability and Turbulence in Hyperthyroidism before, during, and after Treatment. The American Journal of Cardiology 2004, 94, 465-469, doi:10.1016/i.amjcard.2004.04.061.

154. Scheen, A.J. Sibutramine on Cardiovascular Outcome. Diabetes Care 2011, 34, S114-S119, doi:10.2337/dc11-s205.

155. Grundlingh, J.; Dargan, P.I.; El-Zanfaly, M.; Wood, D.M. 2,4-Dinitrophenol (DNP): A Weight Loss Agent with Significant Acute Toxicity and Risk of Death. J. Med. Toxicol. 2011, 7, 205-212, doi:10.1007/s13181-011-0162-6.

156. Langeveld, M.; Tan, C.Y.; Soeters, M.R.; Virtue, S.; Ambler, G.K.; Watson, L.P.E.; Murgatroyd, P.R.; Chatterjee, V.K.; Vidal-Puig, A. Mild Cold Effects on Hunger, Food Intake, Satiety and Skin Temperature in Humans. Endocrine Connections 2016, 5, 65-73, doi:10.1530/EC-16-0004.

157. Dulloo, A.G. The Search for Compounds That Stimulate Thermogenesis in Obesity Management: From Pharmaceuticals to Functional Food Ingredients: Thermogenic Bioactive Food Ingredients. Obesity Reviews 2011, 12, 866-883, doi:10.1111/j.1467-789X.2011.00909.x.

158. Tsai, V.W.W.; Husaini, Y.; Sainsbury, A.; Brown, D.A.; Breit, S.N. The MIC-1/GDF15-GFRAL Pathway in Energy Homeostasis: Implications for Obesity, Cachexia, and Other Associated Diseases. Cell Metabolism 2018, 28, 353-368, doi:10.1016/i.cmet.2018.07.018.

159. Zimmers, T.A.; Fishel, M.L.; Bonetto, A. STAT3 in the Systemic Inflammation of Cancer Cachexia. Seminars in Cell \& Developmental Biology 2016, 54, 28-41, doi:10.1016/j.semcdb.2016.02.009.

160. Ahfeldt, T.; Schinzel, R.T.; Lee, Y.-K.; Hendrickson, D.; Kaplan, A.; Lum, D.H.; Camahort, R.; Xia, F.; Shay, J.; Rhee, E.P.; et al. Programming Human Pluripotent Stem Cells into White and Brown Adipocytes. Nat Cell Biol 2012, 14, 209-219, doi:10.1038/ncb2411.

161. Blondin, D.P.; Labbé, S.M.; Tingelstad, H.C.; Noll, C.; Kunach, M.; Phoenix, S.; Guérin, B.; Turcotte, É.E.; Carpentier, A.C.; Richard, D.; et al. Increased Brown Adipose Tissue Oxidative Capacity in Cold-Acclimated Humans. The Journal of Clinical Endocrinology \& Metabolism 2014, 99, E438-E446, doi:10.1210/jc.2013-3901.

162. Li, H.; Zhang, C.; Liu, J.; Xie, W.; Xu, W.; Liang, F.; Huang, K.; He, X. Intraperitoneal Administration of Follistatin Promotes Adipocyte Browning in High-Fat Diet-Induced Obese Mice. PLoS ONE 2019, 14, e0220310, doi:10.1371/journal.pone.0220310.

163. Ozguven, S.; Ones, T.; Yilmaz, Y.; Turoglu, H.T.; Imeryuz, N. The Role of Active Brown Adipose Tissue in Human Metabolism. Eur J Nucl Med Mol Imaging 2016, 43, 355-361, doi:10.1007/s00259-015-3166-7.

164. Shankar, K.; Kumar, D.; Gupta, S.; Varshney, S.; Rajan, S.; Srivastava, A.; Gupta, A.; Gupta, A.P.; Vishwakarma, A.L.; Gayen, J.R.; et al. Role of Brown Adipose Tissue in Modulating Adipose 
Tissue Inflammation and Insulin Resistance in High-Fat Diet Fed Mice. European Journal of Pharmacology 2019, 854, 354-364, doi:10.1016/j.ejphar.2019.02.044.

165. Sohn, J.H.; Kim, J.I.; Jeon, Y.G.; Park, J.; Kim, J.B. Effects of Three Thiazolidinediones on Metabolic Regulation and Cold-Induced Thermogenesis. Mol Cells 2018, 41, 900-908, doi:10.14348/molcells.2018.0294. 


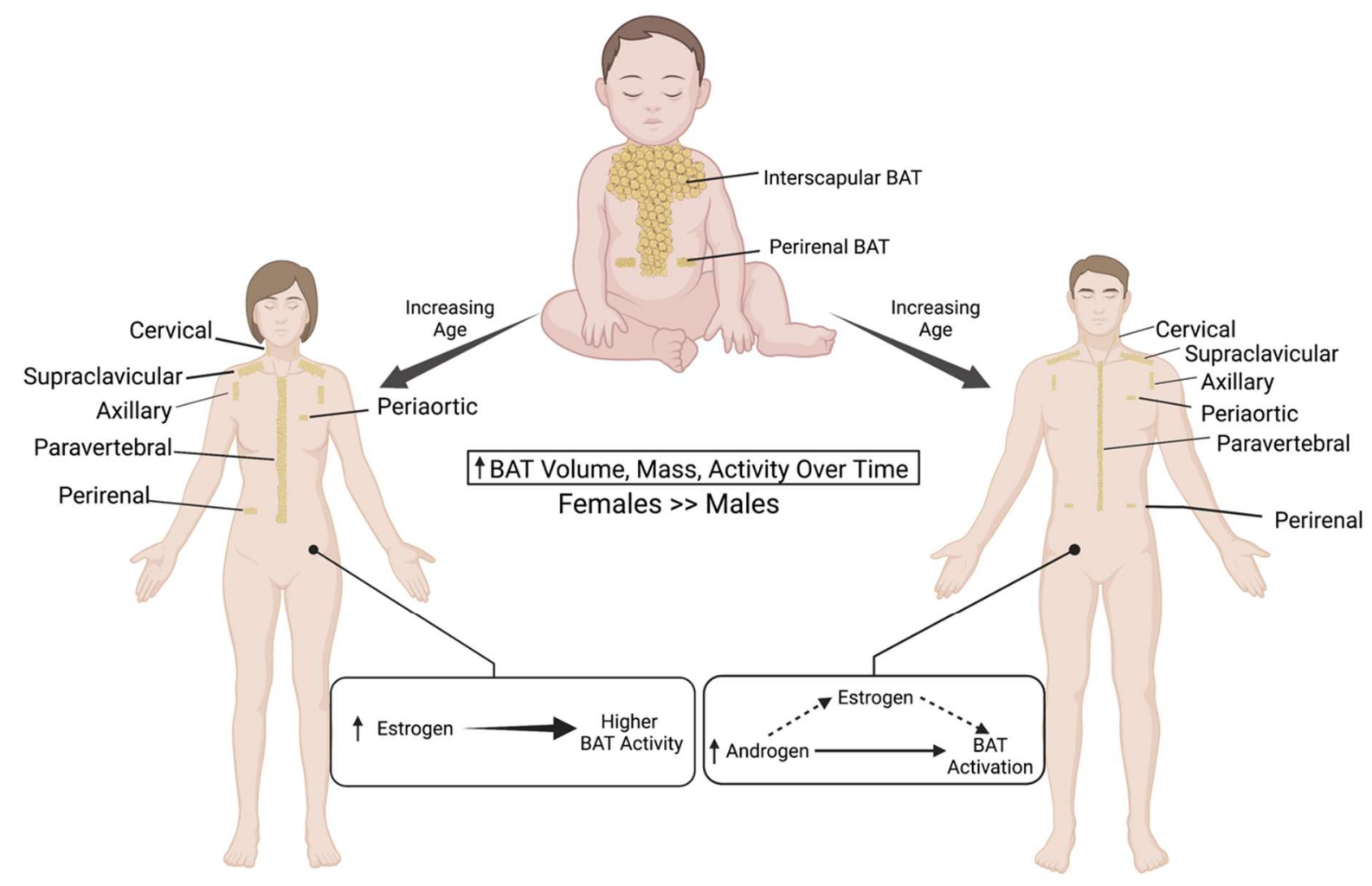

Figure 1. BAT distribution in infants, women and men. BAT is stored in a separate interscapular depot in infants and they lose their brown adipose tissue as they age. In adult humans, most brown adipocytes can be found in the supraclavicular BAT depots in the neck region. Lesser amounts of BAT are found across the aorta, vertebrae, axillary, and kidney areas. There is a similar distribution of brown adipose tissue in both women and men. However, women have a greater amount of BAT mass and activity. Sex hormones are important contributors of the observed gender difference. (Created with BioRender.com) 


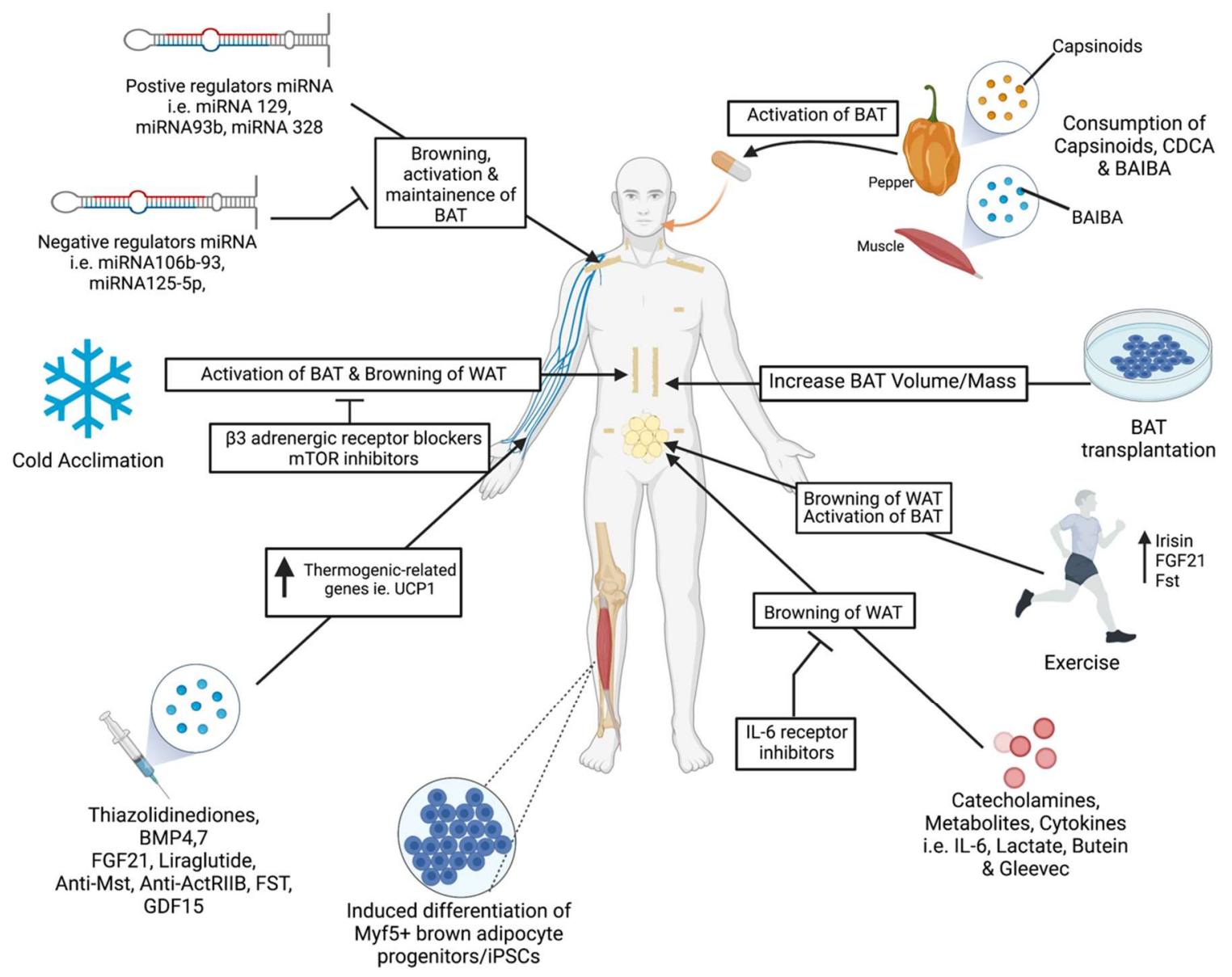

Figure 2: Therapeutic interventions to increase BAT mass/volume. Acute or chronic cold exposure activate BAT metabolism or induce BAT browning. $\beta 3$-AR blockers and mTOR inhibitors, inhibits browning of WAT and activation of BAT. Exercise activate BAT and induce WAT browning via upregulation of irisin, follistatin, and FGF21. Intravenous (IV) administration of proteins i.e. FGF21 and follistatin, antibodies that inhibits Activin receptor type 2B and Myostatin, or pharmaceutical agents i.e. Liraglutide, and thiazolidinediones, upregulate thermogenic-related genes like UCP1 to induce browning of WAT to brite/beige adipocytes. WAT browning is also induced through the use of Gleevec, lactate, and Butein. Certain cytokines, catecholamines, and metabolites were used for browning of WAT. IL- 6 receptor inhibitors block browning of WAT. BAT transplantation increase BAT mass, improve metabolism, and induce BAT activity. MiRNA target regulatory mechanisms to positively induce thermogenesis and browning of WAT like miRNA129 Certain miRNAs are negative regulators of adipose browning in WAT like miRNA 125-5p. Transdifferentiation of induced pluripotent stem cells and mesenchymal progenitor cells into brown adipocytes by targeting regulatory mechanisms to overexpress thermogenic and adipogenic genes. Diet or consumption of oral supplements shown to activate BAT, like capsinoids and BAIBA that can be extracted and utilized as an IV injection or as an oral supplement. (Created with BioRender.com) 


\section{Table 1: Adipose browning studies in human and rodent studies}

\begin{tabular}{|c|c|c|c|}
\hline Model & Design & Factors Measured & Findings \\
\hline Human & $\begin{array}{l}\text { Tested } 17 \text { healthy subjects in } 15-16^{\circ} \mathrm{C} \text { with } \\
\text { increasing time to } 6 \text { hrs/day for } 10 \text { days with } \\
\text { FDG-PET/CT \& abdominal subcutaneous fat } \\
\text { biopsy [77] }\end{array}$ & $\begin{array}{l}\text { Glucose uptake in BAT } \\
\text { \& WAT, energy } \\
\text { expenditure, RMR, and } \\
\text { NST. }\end{array}$ & $\begin{array}{l}\text { Both females \& males in cold exposure: } \\
\text { NST } \uparrow \text {, Detectable BAT volume } \uparrow \text {. } \\
\text { BAT activity } \uparrow \uparrow \text {, Energy expenditure } \uparrow \text {. }\end{array}$ \\
\hline Human & $\begin{array}{l}\text { Single-blinded, placebo-controlled clinical } \\
\text { trial. Exposed to } 17^{\circ} \mathrm{C} \text { for } 2 \text { hrs/day for } 6 \\
\text { weeks. Subjects with undetectable BAT were } \\
\text { placed in cold }(n=12) \text { and control }(n=10) \\
\text { groups. Capsinoid capsules with } 9 \text { or } 0 \\
\text { mgs/day given for } 6 \text { weeks. [120] }\end{array}$ & $\begin{array}{l}\text { Body fat content; } \\
\text { metabolic activity; EE; } \\
\text { FDG-PET/CT utilized. }\end{array}$ & $\begin{array}{l}\text { After cold exposure: BAT activity } \uparrow \uparrow \text { in BAT } \\
+ \text { than in BAT- groups. } \\
\text { Beige adipocytes recruited by BAT via cold } \\
\& \text { capsinoid treatment. } \\
\text { Capsinoids } \rightarrow \uparrow \uparrow \text { BAT thermogenesis \& } \\
\text { recruited BAT. }\end{array}$ \\
\hline Human & $\begin{array}{l}\text { A study between BAT \& adiposity in } 162 \\
\text { healthy volunteers ( } 103 \text { males } \& 59 \\
\text { females). FDG-PET/CT scan after } 2 \text { hrs at } \\
19^{\circ} \mathrm{C} \text {. [85] }\end{array}$ & $\begin{array}{l}\text { BMI, serum leptin, areas } \\
\text { of visceral \& } \\
\text { subcutaneous fat. }\end{array}$ & $\begin{array}{l}41 \% \text { of subjects was found with cold- } \\
\text { activated BAT. } \\
\text { Detectable BAT } \downarrow \text { with } \uparrow \text { age, with BAT } \\
\text { found in } 50 \% \text { of } 20 \text { year olds and }>10 \% \text { in } \\
50 \text { year olds. }\end{array}$ \\
\hline Human & $\begin{array}{l}\text { Clinical trial with } 15 \text { subjects underwent cold } \\
\text { exposure for } 120 \text { min at } 14^{\circ} \mathrm{C} \text {. Treated with } \\
200 \mathrm{mg} / \text { os mirabegron or placebo in a } \\
\text { double blinded trial. [90] }\end{array}$ & $\begin{array}{l}\text { Detected \& quantified } \\
\text { mirabegron via Agilent } \\
6460 \text { LC-MS/MS triple } \\
\text { quadrupole mass } \\
\text { spectrometer. }\end{array}$ & $\begin{array}{l}\text { Cold exposure } \rightarrow \uparrow \text { Resting metabolic rate. } \\
\text { Mirabegron } \rightarrow \uparrow \text { BAT glucose uptake. } \\
\text { No correlation between drug- } \& \text { cold- } \\
\text { stimulation to measure BAT mass or } \\
\text { activity. }\end{array}$ \\
\hline Human & $\begin{array}{l}\text { Prospective study analyzed } 5,907 \text { patients } \\
\text { with }{ }^{18} \mathrm{~F}-\mathrm{FDG} \mathrm{PET} / \mathrm{CT} \text { scanning, but } \\
\text { stringent standards } \rightarrow \text { analysis of only } 100 \\
\text { patients. [163] }\end{array}$ & $\begin{array}{l}\text { Focal FDG uptake, } \\
\text { blood glucose, liver fat } \\
\text { content, lipid panel } \\
\text { (Total, HDL, and LDL } \\
\text { cholesterol; ALT; AST; } \\
\text { triglycerides). }\end{array}$ & $\begin{array}{l}8 \text { men and } 17 \text { women } \rightarrow \uparrow \text { brown fat uptake } \\
\text { [ABAT }(+) \text { group]. } \\
\text { Total \& LDL cholesterol } \downarrow \text { in ABAT }(+) \text { vs. } \\
\text { ABAT }(-) \text {. } \\
\text { Prevalence of NAFLD } \uparrow \text { in ABAT }(-) \text { vs. } \\
\text { ABAT }(+) \text {. } \\
\text { ABAT } \rightarrow \downarrow \text { serum transaminases (ALT \& } \\
\text { AST). }\end{array}$ \\
\hline Human & $\begin{array}{l}10 \text { lean \& } 14 \text { overweight men on cold } \\
\text { exposure for } 2 \text { hrs. FDG-PET/CT scan for } \\
\text { BAT activity. [14] }\end{array}$ & $\begin{array}{l}\text { BAT activity \& volume, } \\
\text { skin \& core temperature, } \\
\text { BMI }\end{array}$ & $\begin{array}{l}\text { BAT activity } \downarrow \text { in obese subjects vs. lean } \\
\text { subjects. } \\
\text { BAT volume } \downarrow \text { in obese subjects vs. lean } \\
\text { subjects. }\end{array}$ \\
\hline Human & $\begin{array}{l}6 \text { non-acclimated men placed in } 10^{\circ} \mathrm{C} \\
\text { environment for } 2 \text { hrs daily for } 4 \text { weeks. } \\
\text { Subjected to electromyography and PET } \\
\text { with }\left[{ }^{11} \mathrm{C}\right] \text { acetate } \&\left[{ }^{18} \mathrm{~F}\right] \text { FDG. [161] }\end{array}$ & $\begin{array}{l}\text { Shivering intensity; BAT } \\
\text { metabolism; fractional } \\
\text { glucose uptake; insulin; } \\
\text { triglycerides; } \mathrm{T}_{3} ; \mathrm{T}_{4} ; \\
\text { ACTH; leptin levels }\end{array}$ & $\begin{array}{l}1.9 \text {-fold } \uparrow \text { in thermogenic rate in cold } \\
\text { exposure. } \\
\text { Total BAT volume and activity } \uparrow \text { by } 45 \% \\
\text { after } 4 \text { weeks. } \\
\text { Fractional glucose uptake } \uparrow \text { in } \\
\text { supraclavicular BAT. }\end{array}$ \\
\hline Mouse & $\begin{array}{l}\text { C57BI/6 mice with FGF21-KO phenotype } \\
\text { subjected } \rightarrow 5^{\circ} \mathrm{C} \text { for } 72 \text {-hour period. } \\
\text { Extracted brown fat pads and subjected for } \\
\text { RNA isolation, immunohistochemistry, and } \\
\text { western blot analysis. [98] }\end{array}$ & $\begin{array}{l}\text { Temperature, } \\
\text { confluence of BAT in } \\
\text { culture, PGC-1a mRNA } \\
\text { expression. }\end{array}$ & $\begin{array}{l}\text { Single-dose recombinant FGF21 } \rightarrow \uparrow \\
\text { browning of WAT. } \\
\text { Cold exposure } \& \beta 3 \text {-AR stimulation } \rightrightarrows \uparrow \\
\text { FGF21 in BAT \& thermogenically } \\
\text { competent WAT depots. } \\
\text { FGF21 absence } \rightarrow \text { impaired adaptive } \\
\text { thermogenesis. } \\
\text { PGC-1a required for FGF21's function. }\end{array}$ \\
\hline Mouse & $\begin{array}{l}\text { Treated hESCs \& hiPSCs to induce } \\
\text { embryoid bodies and adipogenic } \\
\text { differentiation for } 21 \text { days. Subcutaneously } \\
\text { transplanted adipocytes in Rag2---; II2yc } \\
\text { mice. Infused FGF21 or saline pumps } \\
\text { transplanted to interscapular region. [160] }\end{array}$ & $\begin{array}{l}\text { Lipolysis activity; } \\
\text { adiponectin \& leptin } \\
\text { expression; glucose } \\
\text { uptake; oxygen } \\
\text { consumption }\end{array}$ & $\begin{array}{l}\text { Converted hPSCs } \rightarrow \text { MPCs } \rightarrow \text { BAT \& WAT } \\
\text { Doxycycline treatment } \rightarrow \uparrow \text { PPARG } \rightarrow \uparrow \uparrow \\
\text { WAT phenotype. PPARG2-CEBPB- } \\
\text { PRDM16 axis programmed BAT. } \\
\text { Transplantation of hPSC-derived } \\
\text { adipocytes } \rightarrow \text { mature functionality. }\end{array}$ \\
\hline Mouse & $\begin{array}{l}\text { 6-8 weeks old mice fed with HFD for } 8 \\
\text { weeks prior to BAT transplantation; no cold } \\
\text { exposure. [164] }\end{array}$ & $\begin{array}{l}\text { Body weight, basal } \\
\text { glucose levels, and } \\
\text { insulin tolerance. }\end{array}$ & $\begin{array}{l}\text { BAT transplantation-1HFD-induced obesity; } \\
\uparrow \text { Glucose tolerance; } \downarrow \text { Insulin resistance. } \\
\text { BAT removal } \rightarrow \downarrow \text { diet-induced obesity \& } \\
\text { insulin resistance. }\end{array}$ \\
\hline Mouse & $\begin{array}{l}\text { Study with strain-, sex-, and age-matched } \\
\text { donor mice, whose BAT transplanted to } \\
\text { other mice. Recipient mice fed on HFD, post } \\
\text { transplantation for } 20 \text { weeks; cold exposure } \\
\text { utilized. [5] }\end{array}$ & $\begin{array}{l}\text { Body weight, total body } \\
\text { fat (\%), body } \\
\text { temperature, } \mathrm{O}_{2} \\
\text { consumption, mRNA }\end{array}$ & $\begin{array}{l}\text { BAT transplantation } \rightarrow \downarrow \text { HFD-induced } \\
\text { weight gain; } \\
\downarrow \text { Total fat; } \uparrow \text { core body temperature; } \uparrow \\
\text { mRNA of FA oxidation-related genes; } \downarrow \\
\text { HFD-induced insulin resistance; } \downarrow \text { HFD- } \\
\text { induced hepatic steatosis \& obesity. }\end{array}$ \\
\hline Mouse & $\begin{array}{l}\text { 12-week-old male C57BL/ } 6 \text { mice as recipient } \\
\text { mice fed standard food and was } \\
\text { transplanted into visceral cavity with } 0.1 \text { or }\end{array}$ & $\begin{array}{l}\text { Glucose concentration \& } \\
\text { uptake; food \& water } \\
\text { intake; } \mathrm{CO}_{2} \& \text { heat }\end{array}$ & $\begin{array}{l}\text { BAT transplantation } \rightarrow \uparrow \text { glucose tolerance } \\
\& \text { insulin sensitivity; } \uparrow \text { BAT mass } \rightarrow \uparrow \\
\text { metabolic homeostasis. }\end{array}$ \\
\hline
\end{tabular}




\begin{tabular}{|c|c|c|c|}
\hline & $\begin{array}{l}0.4 \mathrm{~g} \text { BAT, or } 0.1 \mathrm{~g} \text { WAT from epididymal fat } \\
\text { pad. [6] }\end{array}$ & $\begin{array}{l}\text { production; plasma } \\
\text { lipids, hormones \& } \\
\text { proteins. }\end{array}$ & $\begin{array}{l}\text { BAT transplantation } \rightarrow \text { more favorable } \\
\text { circulating lipid and hormonal profile; } \uparrow \uparrow \\
\text { circulating norepinephrine concentration \& } \\
\text { 5-fold increase in serum FGF21 levels. }\end{array}$ \\
\hline Mouse & $\begin{array}{l}\text { TZDs (Lobe, Rosi, and Pio) tested on cold } \\
\text { acclimated 10-week-old C57BLKS/J-Leprdb/ } \\
\text { Leprdb male mice for } 4 \text { weeks. Raw264.7 } \\
\text { macrophages \& 3T3-cells treated with TZDs. } \\
\text { [165] }\end{array}$ & $\begin{array}{l}\text { Blood glucose; Glucose } \\
\text { uptake; body weight; } \\
\text { serum triglycerides, } \\
\text { cholesterol, and FFA. }\end{array}$ & $\begin{array}{l}\text { TZDs promoted adipocyte differentiation. } \\
\text { Lobe stimulation >> two TZDs (Rosi \& Pio) } \\
\rightarrow \uparrow \uparrow \text { effect. } \\
\text { Lobe } \rightarrow \uparrow \text { beige adipocyte formation } \\
\& \downarrow \text { proinflammatory signals in leukocytes \& } \\
\text { adipocytes. }\end{array}$ \\
\hline Mouse & $\begin{array}{l}\text { After acclimation, } 4 \text { - to } 6 \text {-week-old C57BL/6J } \\
\text { male mice put on high fat diet for } 8 \text { weeks. } \\
\text { Post- } 8 \text { weeks, intraperitoneal injection of } 8.5 \\
\text { ug/kg of recombinant follistatin (once/day for } \\
\text { one week). [162] }\end{array}$ & $\begin{array}{l}\text { Rectal temperature, } \\
\text { mice activity; } \mathrm{O}_{2} \\
\text { consumption; } \mathrm{CO}_{2} \\
\text { production; glucose } \\
\text { tolerance. }\end{array}$ & $\begin{array}{l}\downarrow \text { HFD-induced obesity; } \uparrow \text { insulin sensitivity. } \\
\uparrow \text { subcutaneous fat browning via AMPK- } \\
\text { PGC1a-irisin signaling pathway. } \\
\uparrow \text { metabolism via insulin pathway in beige } \\
\text { adipocytes. }\end{array}$ \\
\hline Mouse & $\begin{array}{l}\text { Male and female heterozygous mice used for } \\
\text { mouse embryonic fibroblasts. C57BL/6 mice } \\
\text { exposed to cold environment for } 8 \mathrm{hrs} \text {. BAT } \\
\text { harvested and compared to thermoneutral } \\
\text { mice. } 0.5 \mathrm{ug} / \mathrm{uL} \text { of FST on brown } \\
\text { preadipocytes for BAT differentiation. [108] }\end{array}$ & $\begin{array}{l}\text { Genotyped embryos, } \\
\text { gene and protein } \\
\text { expressions of browning } \\
\text { \& metabolism-related } \\
\text { genes; } \\
\text { Oxygen consumption. }\end{array}$ & $\begin{array}{l}\text { Follistatin } \rightarrow \uparrow \text { cellular respiration. } \\
\text { Follistatin secreted by AT in a paracrine } \\
\text { manner. } \\
\text { Follistatin } \rightarrow \uparrow \text { brown adipocyte and } \\
\text { thermogenic gene expression in } \\
\text { differentiated brown adipocytes and MEF } \\
\text { cultures from both WT and FST KO mice. }\end{array}$ \\
\hline
\end{tabular}

RMR: Resting Metabolic Rate; NST: Non-shivering Thermogenesis; EE: Energy Expenditure; BMI: Body Mass Index; ABAT: Activated Brown Adipose Tissue; NAFLD: Non-Alcoholic Fatty Liver Disease; ALT: Alanine transaminase; AST: aspartate aminotransferase; LC-MS/MS: Liquid Chromatography with Tandem Mass Spectrometry; T3: triiodothyronine; T4: Thyroxine; ACTH: Adrenocorticotropic hormone; FFA: Free Fatty Acid; FA: Fatty Acid; hESCs: human embryonic stem cells; hiPSCs: human induced pluripotent stem cells; HFD: High Fat Diet; MPCs: Mesodermal Progenitor Cells; MEF: Mouse embryonic fibroblast 